\title{
Building a Secondary Containment System
}

Michael F. Broder 


\section{DISCLAIMER}

This report was prepared as an account of work sponsored by an agency of the United States Government. Neither the United States Government nor any agency thereof, nor any of their employees, make any warranty, express or implied, or assumes any legal liability or responsibility for the accuracy, completeness, or usefulness of any information, apparatus, product, or process disclosed, or represents that its use would not infringe privately owned rights. Reference herein to any specific commercial product, process, or service by trade name, trademark, manufacturer, or otherwise does not necessarily constitute or imply its endorsement, recommendation, or favoring by the United States Government or any agency thereof. The views and opinions of authors expressed herein do not necessarily state or reflect those of the United States Government or any agency thereof. 


\section{DISCLAIMER}

Portions of this document may be illegible in electronic image products. Images are produced from the best available original document. 


\title{
BUILDING A SECONDARY CONTAINMENT SYSTEM
}

\author{
Michael F. Broder, PE 1
}

\begin{abstract}
Retail fertilizer and pesticide dealers across the United States are installing secondary containment at their facilities or are seriously considering it. Much of this work is in response to new state regulations; however, many dealers not facing new regulations are upgrading their facilities to reduce thcir liability, lower their insurance costs, or comply with anticipated regulations. The Tennessee Valley Authority's (TVA) National Fertilizer and Environmental Research Center (NFERC) has assisted dealers in 22 states in retrofitting containment to their facilities. Simultaneous improvements in the operational efficiency of the facilities have been achieved at many of the sites. This paper is based on experience gained in that work and details the rationale used in planning secondary containment and facility modifications.
\end{abstract}

\section{Introduction}

As a result of the Clean Water Act of 1987 and subsequent regulations enacted or under development by states, the majority of fertilizer and pesticide dealers across the Nation will be required to install or improve secondary containment at their facilities. At present, only ten states have secondary containment regulations affecting fertilizer and pesticide dealers. Several other states are at various stages in developing their own regulations. Even in the remaining states where no regulations are being considered, dealers are becoming increasingly concemed about their liability for both existing and potential soil and water contamination resulting from their operations.

Approximately 10,000 fertilizer retailers in the United States blend and apply fertilizers and pesticides (Hargett and Berry, 1988). A few of these dealers may choose to construct an entirely new facility on other parts of their property or at a new location. However, most will choose to remodel their existing facilities by retrofitting secondary containment at existing product storage areas; at operational areas where materials are received, mixed, and loaded; and where equipment is washed.

In the following discussion, we will talk about issues which affect the planning and construction of secondary containment and ways to improve operational efficiency. We will also discuss some considerations which must be addressed before construction is begun.

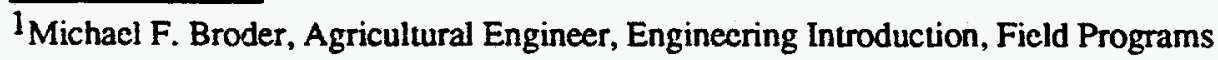
Department/Technology Introduction, National Fertilizer and Environmental Research Center, Tennessee Valley Authority, Muscle Shoals, Alabama 35660.
} 


\section{Part I: Concrete Systems}

\section{Containment}

Containment is keeping pesticides and fertilizers out of the environment until they are applied to cropland. Storage vessels provide primary containment. Secondary containment is "backup" protection against failures of primary vessels and against leaks and spills.

Secondary containment dikes for storage tanks are necessary for environmental security, but the loss of product from a tank failure is much less common than the spills which occur while mixing and loading products. Mixing, loading, and equipment washing areas (operational areas) are the sites of frequent spills which must be contained.

In some areas, poorly designed wells and water connections are the main causes of groundwater contamination. A dealer's water source can be his greatest environmental liability if it is not properly designed to prevent contaminants from entering the water supply.

When upgrading a facility, the location and condition of the three potential sources of soil and groundwater contamination must be considered: water supply, operational areas, and product storage areas.

\section{Existing Facility Evaluation and Planning}

Before designing containment for a facility, a thorough assessment of the existing facility should be made. Many facilities have had more than one owner over the years or have expanded their operations with little or no long-range planning or thought to improving operational efficiency. Consequently, the three main parts of the facility (water supply, operational areas, and storage areas) generally are not designed for efficient operation. The key to retrofitting an existing facility is to improve the efficiency of operation while providing containment.

\section{Operational Assessment}

The operations at a facility which most affect its efficiency are: raw material receiving, mixing, finished-product loading, and equipment washing. An assessment of these areas is performed as part of the overall planning for secondary containment, but it also serves to evaluate the layout of the facility's operations and forms the basis for recommendations for improving efficiency.

Ideally, a facility should be compact, accessible, easy to operate, and expandable. However, what is often the case are facilities with product handling operations scattered over the property or facilities with handling operations so consolidated that they interfere with one another.

Figures 1 and 2 illustrate the two extremes with regard to product handling flexibility. In Figure 1, raw material receiving, equipment washing, and finished-product loading are all done on the same concrete pad which saves construction cost. During the busy shipping season, however, such a facility is likely to have serious logistical problems which could delay the filling of customer orders. 


\begin{tabular}{|c|}
\hline DRY \\
MATERIAL \\
STORAGE \\
\hline
\end{tabular}

\begin{tabular}{|c|}
\hline BULK \\
PESTICIDES \\
STORAGE \\
LIQUID \\
FERTILIZER \\
STORAGE \\
\hline
\end{tabular}

\section{MIXING}

MIXED PRODUCT LOADING

RAW MATERIAL UNLOADING

EQUIPMENT WASHING

DIRECT SA_ES LOADING

\section{Figure 1}

Facility Layout with Handling

Operations Consolidated on One Pad

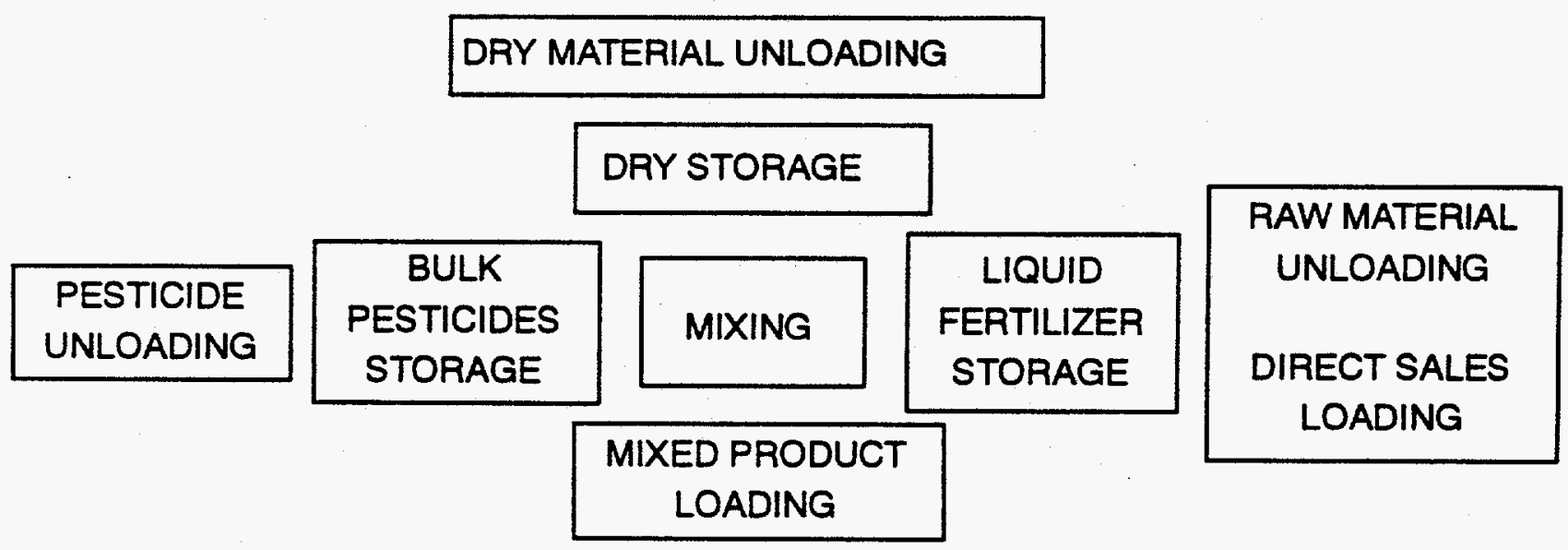

Figure 2

Facility Layout with Handling Operations Separated 
Conversely, if each operation is done in a separate contained area, as in Figure 2, efficiency is improved, but the cost of containment may be prohibitive. Containment cost can be reduced by combining operations in a single containment area. The key to good design is combining operations without sacrificing efficiency. For example, the equipment washing pad in Figure 2 can be eliminated by moving the operation to the raw material receiving area or the product loading area.

In evaluating the efficiency of a facility's present layout and operations, the following points should be considered:

1. How many product loading and unloading areas are there? How many can the dealer afford to contain? How many are actually needed for efficient operation, and how can they be consolidated?

2. Can equipment be washed on one of the loading pads without interfering with shipping or receiving operations?

3. Are existing containment structures adequate? If not, can they be incorporated into a new design?

4. How much rinsate, spilled product, or floor sweepings are being generated, and how might these materials be used or recycled?

5. Will rinsates and scrap fertilizers need to be segregated or can they be kept free of pesticides by changing the way pesticides are handled and by rinsing equipment in the field?

6. Is the mixer restricting output? Should a second mixer be installed or can overhead loadout hoppers or tanks be used? Can a product dump tank be used to speed liquid product output?

7. Are enough raw materials sold directly to justify installing a system to meter them directly into trucks, bypassing the mixer?

8. Is there adequate space at the site to build required containment structures? Is there enough room for expansion?

9. Will the types of products being handled change? Will deliveries continue to be made by rail or truck?

\section{Binsate and Scrap Material_Management}

Serious consideration should be given to management of recycle products: rinsates, floor sweepings, and other residues laden with fertilizers or pesticides. Since fertilizers and pesticides must be applied according to good agronomic and pest control practices, recycled materials must be carefully managed to allow them to be used as originally intended: as fertilizers and pesticides.

To segregate recycle materials, all pesticide spills must be cleaned up immediately and transferred to their proper storage tanks. To reduce the amount of rainfall, which becomes contaminated and must be recycled, loading pads and containment dikes must be kept clean. Otherwise, these areas have to be roofed to keep rainfall out.

A typical system for utilizing recycle materials might involve several storage tanks designated for rinsates from com, soybean, and wheat operations, plus a tank for pesticide-free makeup water. Schemes will vary according to the number of crops treated and the amount of rinsate generated at a facility. Recycle 
materials are usually added to mixes manually using a portable pump. The recycling of these products can be automated by interfacing the rinsate storage with the mixer controls.

If pesticides can be kept out of rinsates, they can all be stored in one tank, avoiding the expense and labor associated with segregating them. This can be done by mixing pesticides with fertilizer or other carrier at the site of application. Monitoring the use of pesticides is more difficult when mixed in the field instead of in the batch mixer; however, much less rinsate is produced since less equipment comes in contact with pesticides. Only the applicator and pesticide containers have to be rinsed, and these are rinsed in the field and their rinsate broadcast in the field last treated.

Onboard herbicide injection and impregnation systems (systems which inject pesticide directly into the applicator's output stream) are ideal for reducing rinsate. However, these systems are limited in the number of products they can handle. Regardless of where pesticides are mixed, the amount of rinsewater handled can be reduced by rinsing as much equipment as possible in the field.

To reduce the chance for rinsates to enter surface water, the rinsing should be done a safe distance from ditches and creeks. When onboard rinse systems are used, the rinsate left in the applicator should be broadcast over the field.

Reusable pesticide containers, closed transfer systems, and use of high-pressure/low-volume rinse equipment are all used to reduce the amount of spilled material and rinsate which must be recycled. Other methods for minimizing pesticide rinsate are described by Broder and Cole (1987).

Dry fertilizer impregnation should be done under roof; otherwise, rainfall contacting pesticide residues in the blender or conveying system must be collected and handled as a dilute pesticide/fertilizer mixture. Spilled materials and product cleaned from the blender should be added in small proportions to other blends. This will dilute pesticide residues enough to allow them to be applied to land without exceeding labeled rates. Any water used to clean the blender must be handled as a dilute pesticide.

Actual field experience is the best guide for determining the importance of recycle product segregation. Dealers who handle pesticides in a well-contained facility can also provide useful information regarding the amount of recycle material generated and potential contamination risks.

When retrofitting facilities, the scheme used to handle recycle materials must be considered because these materials must be contained as do full-strength materials.

\section{Security}

The need for security fencing can influence the layout of facilities. Facilities in areas subject to theft or vandalism should have a security fence with locks on gates around the property. At some dealerships, only product and equipment storage areas are fenced. If fencing is included in a design, consolidation of product and equipment storage areas can reduce the length of fence and associated cost.

Facilities in areas not subject to vandalism may not require a security fence; however, all valves on tanks should be equipped with locks. Since valves on tanks and valves at the bottom of external sight gages both need to be locked, the two can be positioned on each tank so that a single lock can be used to lock both valves. Gravity drains on containment areas are not recommended. However, in some areas, drains are permitted to discharge rainwater. These valves should also be equipped with a security lock. 


\section{Environmental Assessment}

An environmental site assessment (ESA) is a comprehensive and detailed evaluation of a facility's siting, storage areas, operational areas, employee practices, waste handling procedures, and environmentallyrelated documentation. The resulting repon of findings and recommendations details existing and potential environmental concerns and proposes corrective actions based on professional experience and knowledge of regulations and best management practices. The information derived from the assessment can influence secondary containment design and recommendations for improving operations efficiency. It may also influence a dealer's decision about relocating a facility.

ESA checklists have been published for use by dealers (Cole and Tomlinson, 1989; TVA, NFSA, 1990). In general, these are simple and easy to use, can alert the dealer to certain problems, but provide litule information about corrective actions. TVA is developing the "Fertilizer and Agrichemical Dealer Environmental Evaluation," which will allow the dealer to perform the onsite evaluation and will provide professional recommendations based on offsite interpretation of responses to a comprchensive questionnaire.

A formal onsite investigation by an experienced consultant provides the most information, but is also the most expensive, typically $\$ 3,000$ or more. Although the type of assessment performed will depend on the dealer's needs and concerns, in any type of assessment, the primary items of importance are:

1. Fertilizer and pesticide storage and handling areas should be located downgrade and a safe distance from onsite wells.

2. Topography and drainage patterns of stormwater should prevent flow of water into or across storage and transfer areas.

3. Flood plain areas or areas with shallow depth to groundwater should be avoided.

4. The load-bearing capacity of soil should be sufficient for planned structures.

5. Operations which generate airborne emissions (dust, noxious odors, or potentially hazardous gases) should be located away from heavily populated areas and downwind of homes and businesses.

6. If urban sprawl has approached or encircled a facility, serious consideration should be given to relocating in a more rural area.

7. Soil contaminated from past practices requires special consideration. These areas should not be buried under concrete. Options for dealing with contaminated soil are discussed below.

Soil contamination is common at existing loading areas. When fertilizer is the contaminant, it can be land applied according to agronomic recommendations. Pesticide-laden soil can be land applied if application rates can be matched to pesticide levels to ensure natural degradation of the pesticides. Currently, only Illinois has a program which permits land application of pesticide-contaminated soil. Illinois sets maximum application rates based on the characteristics of the land and contamination levels of the soil. In other states, the soil could be considered a hazardous waste, subject to Federal regulations concerning its handling and disposal.

In some instances, natural degradation may break down the pesticide(s) in a relatively short time. If this is known to be the case, then the area should be left undisturbed. 
If the soil has a high permeability and a shallow depth to groundwater, and if the materials are not readily degraded, the site may require remediation. Soil and groundwater analysis and discussion with an environmental consultant may be needed.

Burying contamination under concrete could retard the rate of natural degradation and could lead to an expensive cleanup. If space limitations dictate that an existing contaminated area must remain a site for handling products, the only option a dealer has is to clean up (remediate) the site before constructing containment. Long-term salability of the property should be considered when comparing alternatives.

\section{Retrofitting Containment Systems}

When retrofitting containment to an existing site, the three potential sources of groundwater and soil contamination must be considered: water supplies, operational areas, and product storage areas. Because of the high cost involved, containment construction is often spread over a two- or three-year period. Regulations generally have a similar compliance schedule, and the areas requiring containment are prioritized according to their perceived risk. Dealers should assign the same priorities to their containment construction. Generally, containment is prioritized as follows: water system protection, pesticide storage and operational containment, fertilizer operational containment, and fertilizer storage area containment.

\section{Wellhead Protection}

Poorly designed wells have been found to be the major cause of well water contamination in rural areas. Wells not having a solid casing down to the water bearing strata are generally not permitted. The wellhead should be inspected to ensure that there are no cracks in the casing. The clay fill or concrete pad around the casing should be elevated to force surface water to drain away from the well. Runoff that ponds near the wellhead can easily get into the well by seeping around the well casing or through a crack in the casing. Because of this risk, some states specify a minimum distance between a well and new pesticide/ferilizer handling facilities (lowa, 1988; Illinois, 1989; South Dakota, 1989).

Most states no longer allow installation of wells in frost pits. Dealers having a wellhead in a frost pit should consider extending the casing above the surrounding soil. As a minimum, the pit should be made watertight so that no contaminants can get in. Local officials should be contacted regarding requirements for private wells.

Abandoned or substandard wells should be retired and sealed, which usually requires a permit. The Extension Service or Public Health Office should be contacted for information on well closures.

\section{Water System Protection}

All connections to the water supply system should be inspected to ensure that products cannot enter by back-siphoning. This could happen at the water inlet to the mix tank or where vehicles are filled through a bottom connection. Even hoses submerged in a pool of liquid can back-siphon material if the system loses pressure.

The only acceptable methods for preventing back-siphoning are air break tanks or reduced pressure principle zone (RPZ) valves. Dealers using a single check valve for preventing back-siphoning should replace them with an air break or RPZ valve. 
An air break tank is merely a supply tank which receives water from a water supply system through a pipe which has an air space between the pipe outlet and the highest level attainable in the tank. Generally, the space between the pipe and the maximum water level is twice the pipe diameter.

An RPZ valve is a special device with two independently operating check valves and a pressure differential relief valve between the check valves. When there is a loss of pressure in the water supply, the two check valves close, preventing a reversal of water flow.

\section{Mixing Area Containment}

Incidental spills are common in the mixing area. Spills can occur when materials are added manually to the mixer. Fluid piping systems and conveyors of dry materials often leak. Consequently, most existing facilities have concrete beneath the mixer; however, the concrete surface is generally not properly sloped to facilitate cleanup nor is it curbed to contain a catastrophic spill.

\section{Lianid_Mixing_Areas}

Liquid mixing areas can be contained by installing a curb on three sides of the mixing area, forcing the area to drain onto the loading pad. Some dealers contain their mixer by placing it on their loading pad. Containment can also be achieved by curbing the entire mixing area, making sure the containment volume equals the volume of the mix tank. Figure 3 shows how a curb should be built on an existing slab.

Since liquid fertilizers are quite corrosive to concrete, concrete exposed to frequent fertilizer spills should be sloped at least 2 percent (PCA, 1990). This amount of slope facilitates cleanup and minimizes the effect of corrosive materials. The easiest way to obtain this slope on a flat mix room floor is to pour concrete on top of the existing slab if it is in good condition. If the surface of the existing slab is degraded from corrosion, the crumbly material and all the contaminant should be removed; otherwise, the contaminant can attack the new concrete from underneath.

Mixing area containment should be large enough to accommodate mini-bulk containers, other portable pesticide containers, and rinsate tanks which are not contained in a separate dike.

\section{Dry Mixing_Areas}

Dry mixing is best done under roof. Some dealers protect their blenders from the weather by extending the roof of a fertilizer storage building so it will cover the blender and the loadout conveyor. Other dealers keep the blender under roof and build a concrete pad to collect material falling from the conveyor or spilling over the sides of spreaders and tenders. Blending towers-systems having consignment hoppers, weigh hoppers, and blenders all stacked verically in a tower-should be enclosed and have a roof over the loading area. The pad beneath the tower should be large enough to collect material spilling over the sides of spreaders and tenders as well as material from leaks in the blending system.

Because of the problems associated with rainfall contamination, both liquid and dry mixing areas should be under roof. Otherwise, rainfall coming in contact with fertilizer and pesticides in the mixing area will have to be collected and handled as a dilute fertilizer or pesticide mixture. 


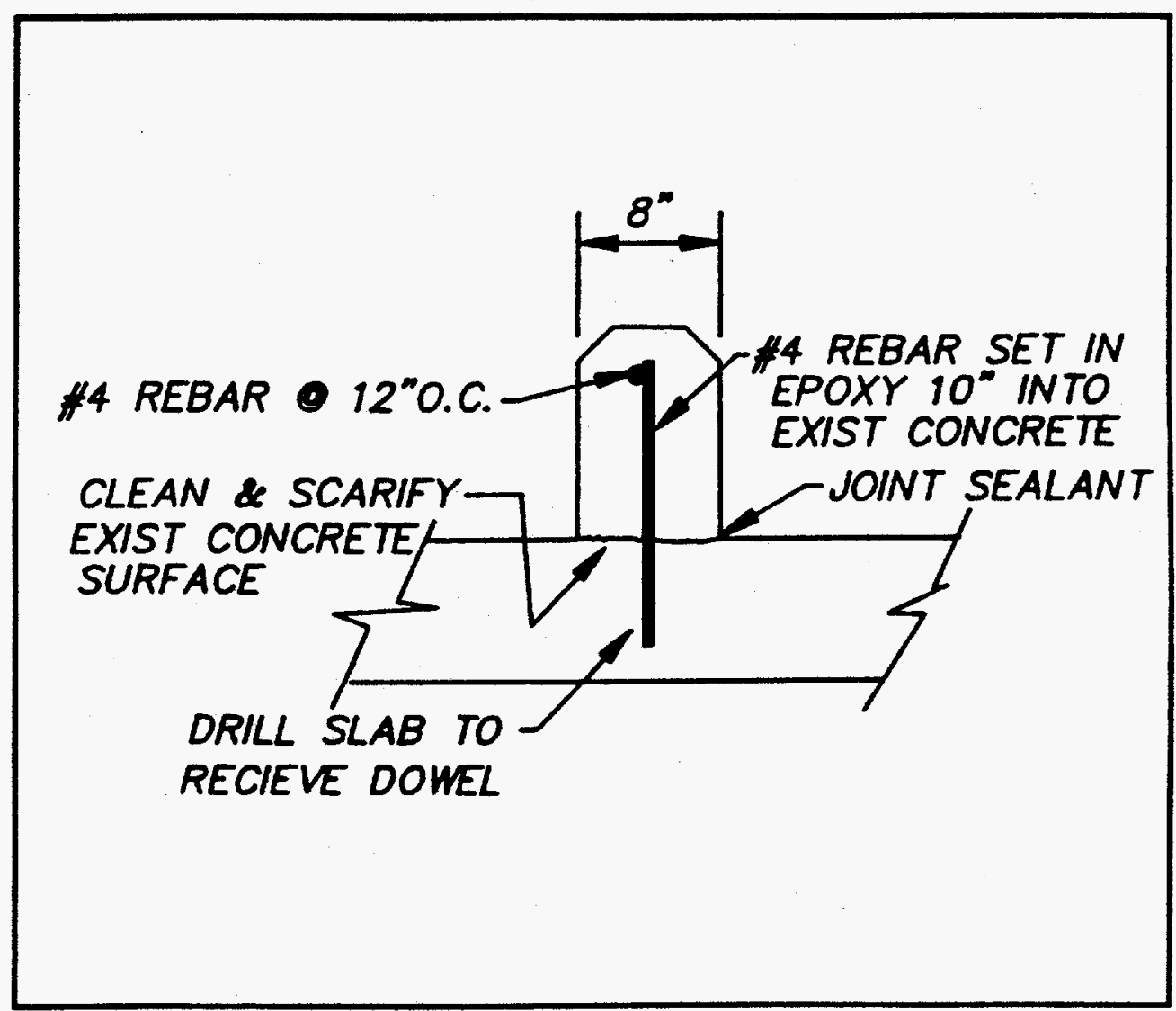

Figure 3

Installing a Concrete Curb on an Existing Slab 


\section{Loading Areas}

Loading areas are sites of frequent spills. Since it is impossible to avoid all spills, provisions must be made to capture spilled material before it escapes to the environment. Product loading and unloading must be done within a watertight basin having a surface from which spills can be collected. Loading pads are usually made of concrete, however, portable ones made of steel, reinforced plastic, and polyethylene are available. Alternative materials will be discussed in Part II of this paper.

If the loading pad is designed for equipment washing, it should be large enough to catch all the wash water. A system for handling solids and dirt, which accumulate from the washing of equipment, is also needed.

As with other operational areas, provisions must be made for handling contaminated rainfall. There are two philosophies for dealing with rainwater at loading areas: one is to roof the area to avoid rainwater problems; the other is to keep the area clean enough to allow rainwater to be discharged.

Roofing the loading area can be costly but it simplifies management of the area since spill cleanup will only be required for pesticide segregation.

A pad which is not under roof will need frequent cleaning to allow rainwater to be discharged. This may appear to be an inconvenience. However, if rinsates and spills are segregated, frequent cleaning is required, even with a roof over the pad. Since spills left on the loading pad can adhere to vehicle tires and be tracked off of the loading pad, the best practice is to clean spills immediately. Loading areas exposed to the weather promote this management practice.

\section{Liquid_Loading_Areas}

Main design features to consider for a liquid product loading pad are liquid holding capacity, pad length and width, sump location, sump design, and pad slope.

Liquid holding capacity is one requirement which varies considerably across state regulations. Pads used to load product out of facilities are required to have volumes ranging from 1,500 gallons to the volume of the largest vehicle loaded; large liquid transports have capacities up to 5,000 gallons (Illinois, 1989; South Dakota, 1989; Wisconsin, 1988). Loading pads used to unload raw materials at facilities have volume requirements ranging from 25 gallons to the volume of the largest vehicle loaded (Illinois, 1989, AAPFCO, 1990). Since incidental spills are common at both loadin and loadout areas, some type of containment is necessary.

Providing the necessary volume on a pad designed to accommodate one vehicle can be difficult. Figure 4 shows such a pad and calculations for determining liquid holding capacity. Note that to hold 4,000 gallons, it is 12 feet wide by 60 feet long and is 2.2 feet lower at the sump if all edges are at the same elevation and all slope to the sump. Sloping two sides of the pad to a central trough (Figure 5) reduces the depth of the pad for a given volume. The top edge of the trough in Figure 5 is 1.5 feet below the height of the edges.

One way to increase the pad volume is to form a roll-over curb (one that vehicles can easily cross) on the perimeter. Adding a 4-inch roll-over curb to the pad in Figure 1 increases its volume by 45 percent (see calculations under Figure 4). 

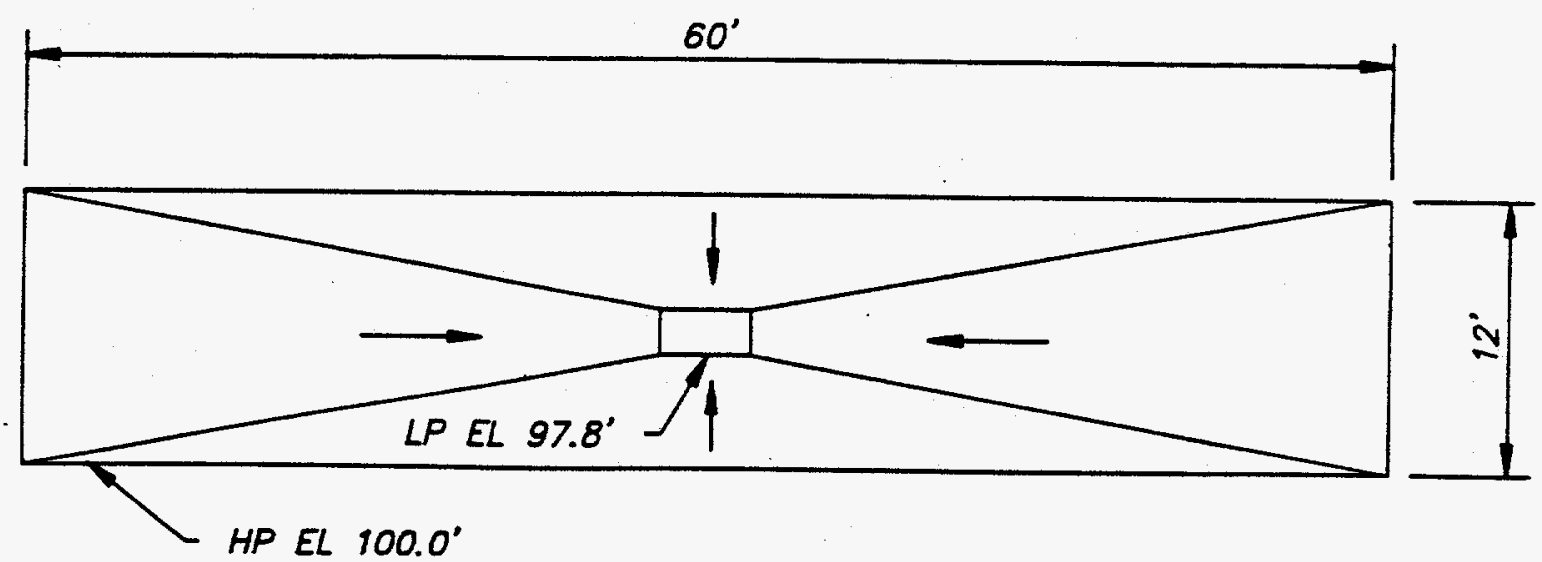

Liquid Holding Capacity in Gallons

$\mathrm{LHC}=\frac{7.5 \times \mathrm{L} \times \mathrm{W} \times \mathrm{D}}{3}$

Where,

$\mathrm{L}=$ pad length in feet

$W=$ pad width in feet

$\mathrm{D}=$ depth at sump inlet in feet

7.5 = gallons per cubic feet

$\begin{aligned} \text { LHC } & =\frac{7.5 \times 60 \times 12 \times 2.2}{3} \\ & =3960 \text { gallons excluding }\end{aligned}$
By adding a 4" high rollover curb around the pad the LHC is increased by 1800 gallons. LHC of the curb is computed as follows:

$\mathrm{LHC}=7.5 \times \mathrm{L} \times \mathrm{W} \times \mathrm{CH}$

where,

$\mathrm{CH}=$ curb height in feet

LHC $=7.5 \times 60 \times 12 \times 0.33$

$\mathrm{LHC}=1800$ gallons

Figure 4

Load Pad with a Central Sump and Volume Calculations

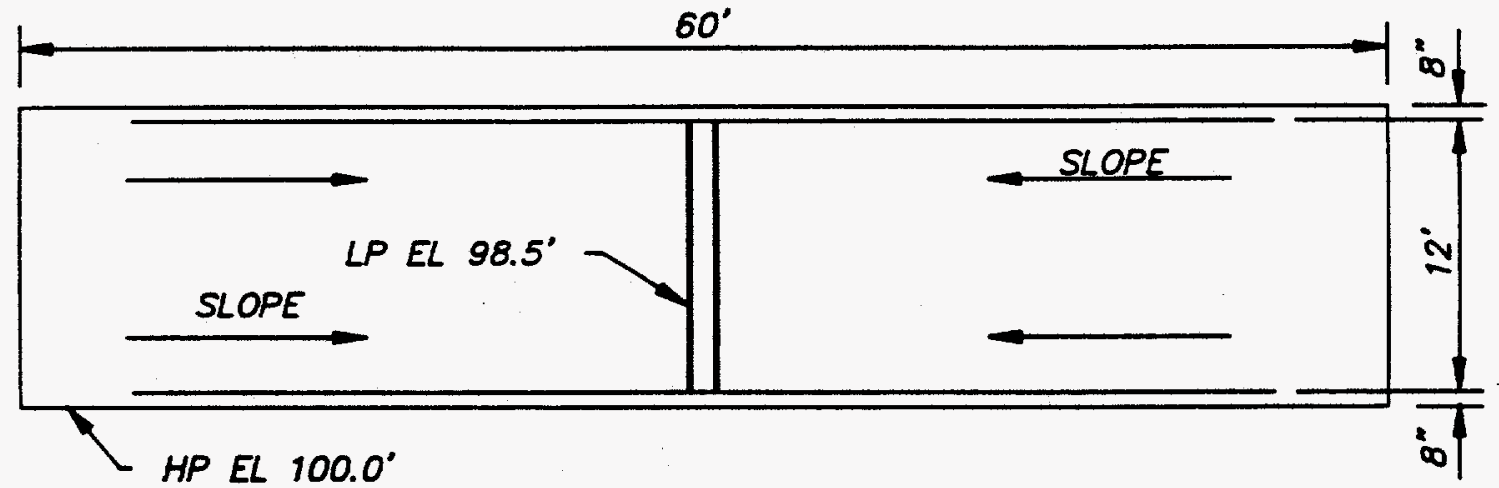

The liquid Holding Capacity for this pad is

computed by the equation

$\mathrm{LHC}=7.5 \times \mathrm{L} \times \mathrm{W} \times \mathrm{D}$

2

LHC $=7.5 \times 60 \times 12 \times 1.5$

2

$\mathrm{LHC}=4,050$ gallons excluding the trough

Figure 5

Load Pad with a Trough and Volume Calculations 
Some states permit the volume requirement to be met by using an automatic sump pump connected to a storage tank (Wisconsin, 1988; and Illinois, 1989). A more reliable approach is to provide for overflow to another basin. This is done most easily by locating the loadout pad at a higher elevation than the secondary containment dike.

Buried tanks or pits should not be used to store liquid from loading pads. Any such systems șhould be removed or retired. This involves a thorough cleaning, sealing all inlets, and filling with a flowable concrete fill. Flowable concrete is a mixture of sand and water with a little cement. Another type of inexpensive fill material available in some areas is concrete made with fly ash instead of cement.

Pad width and length should be based on the work it is to accommodate. A pad for equipment washing should be at least 20 feet wide. If the pad is to be used for loading and unloading, it should be wide or long enough to accommodate two vehicles. State regulations generally have no minimum dimensions for loading pads; however, a general rule is that the trailer or tank of the largest vehicle loaded should fit within the borders of the pad. The tractor on semitrailer rigs, therefore, does not need to fit inside the pad borders.

Pad slope should be at least 2 percent to reduce the corrosive effects of fertilizers and facilitate washdowns. Slope configurations vary according to sump location and design. Figures 4 and 5 show how pads are sloped to a trough or rectangular sump. Rinsate and spilled product segregation can be facilitated by sloping the pad to separate sumps as shown in Figure 6. Another way to segregate these materials is to slope the pad to a wall where multiple drains and valves are used to direct material to appropriate sumps for subsequent pumping to designated storage tanks (Figure 7).

Sump location will depend on how it is to be used and how vehicles travel across the pad. If vehicles are to enter from all four sides, the sump needs to be near the center of the pad. A disadvantage of centering the sump is that it can interfere with product movement if the sump must be cleaned out or manually pumped out as product is being loaded. Often the sump is placed on one side of the pad. Then the pad is still accessible from three sides.

The trough shown in Figure 5 is preferred by many dealers because it facilitates level parking of vehicles. The trough bottom can be sloped to convey material to one side of the pad, while providing a large area for collecting solids and debris.

Sump designs vary according to how or whether they are used to handle solids. Some dealers can slurry solids into liquids and are not concerned with solids which accumulate in the sump. Other dealers go to great lengths to separate solids from liquids being recycled. These dealers use either an extra sump for solids removal or use a trough or sediment trap around the sump. Figures 8 and 9 illustrate loading pads with sumps designed for solids removal. A sump with a drain some distance above the bottom, as shown in Figure 9, can be fitted with a pan for collecting solids. Solids are removed by dumping the pan. Collected solids should not be discarded like dirt. Sediment collected in sumps where pesticides have been handled can contain fairly high concentrations of pesticides. Two ways to recycle these pesticide-laden solids are to slurry them into fluid fertilizer or add them to dry fertilizer in quantities small enough to permit application at or below labeled rates.

Sumps should be made as shallow and small as practical for several reasons. The labor associated with cleaning out a sump dictates that it be small. If rinsates are segregated, or if the loading pad is exposed to rainfall, a small sump is recommended since it will require frequent cleaning. This is also the case in states where regulations stipulate that sumps be cleaned out at a certain frequency, such as each working day or every 72 hours. 


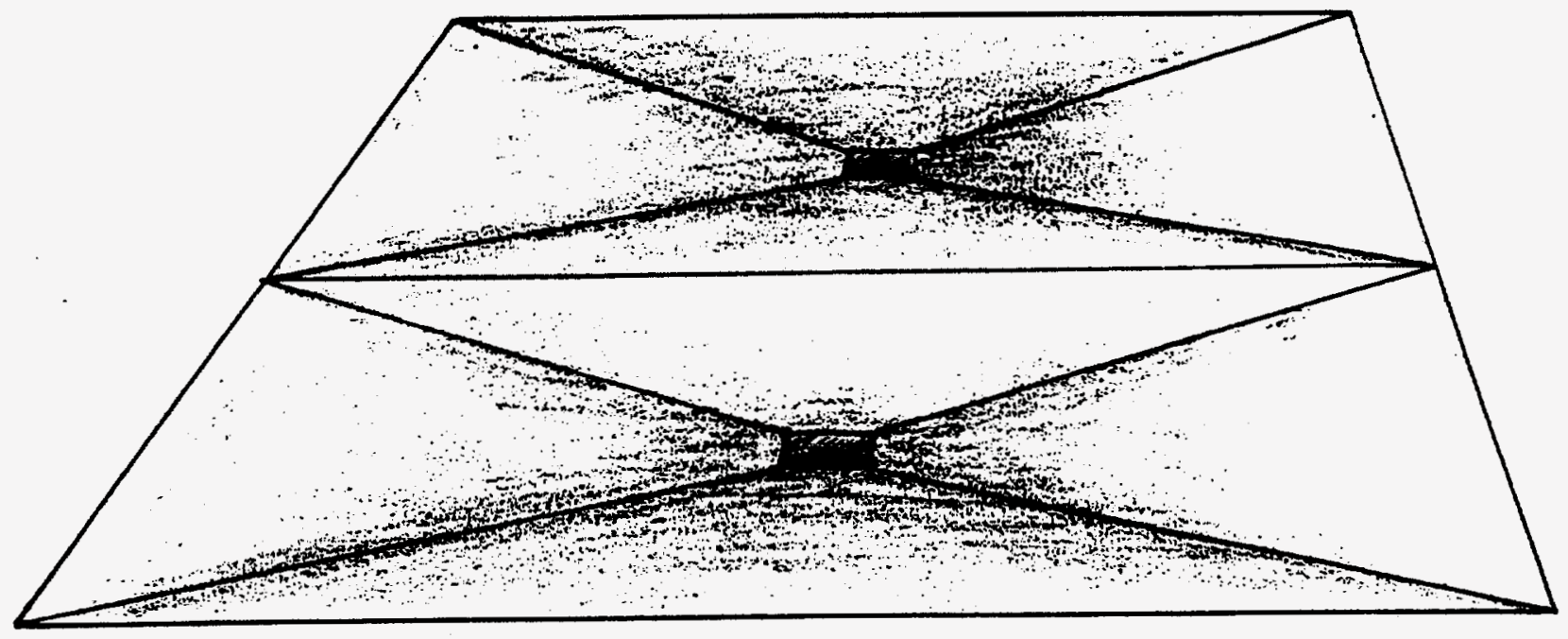

Figure 6

Double Load Pad with Separate Sumps

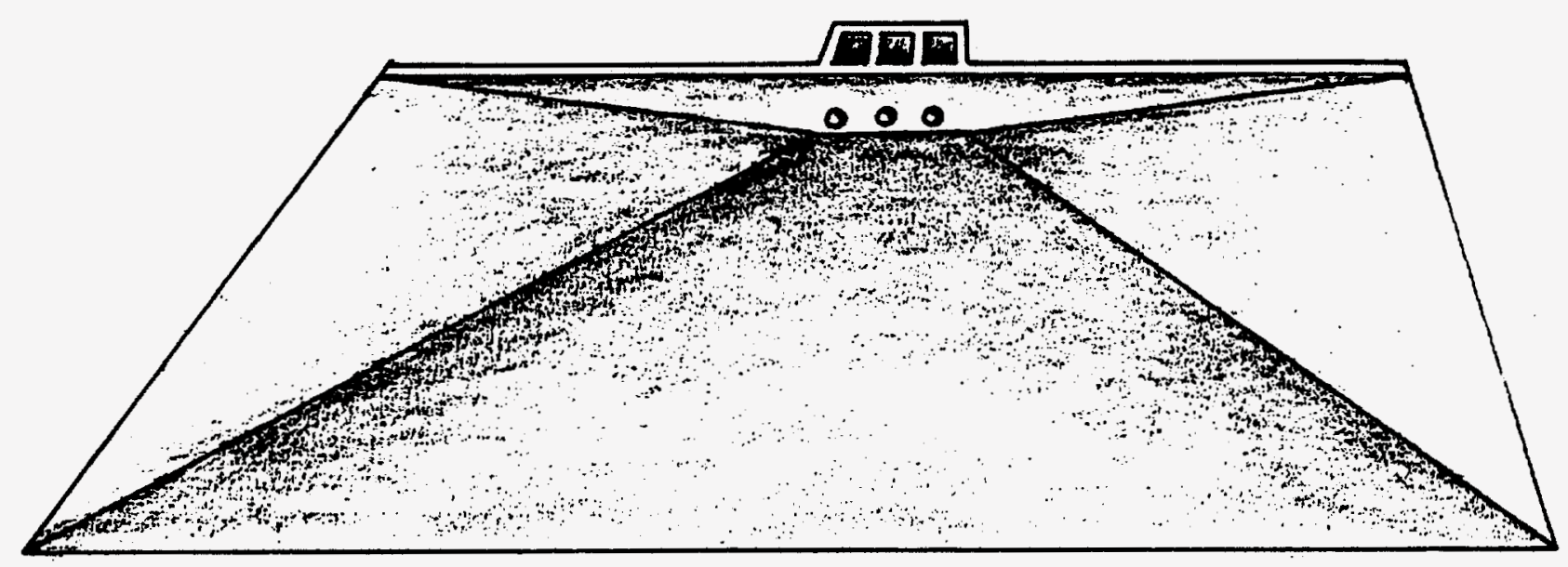

Figure 7

Load Pad with Multiple Drains for Rinsate Segregation 


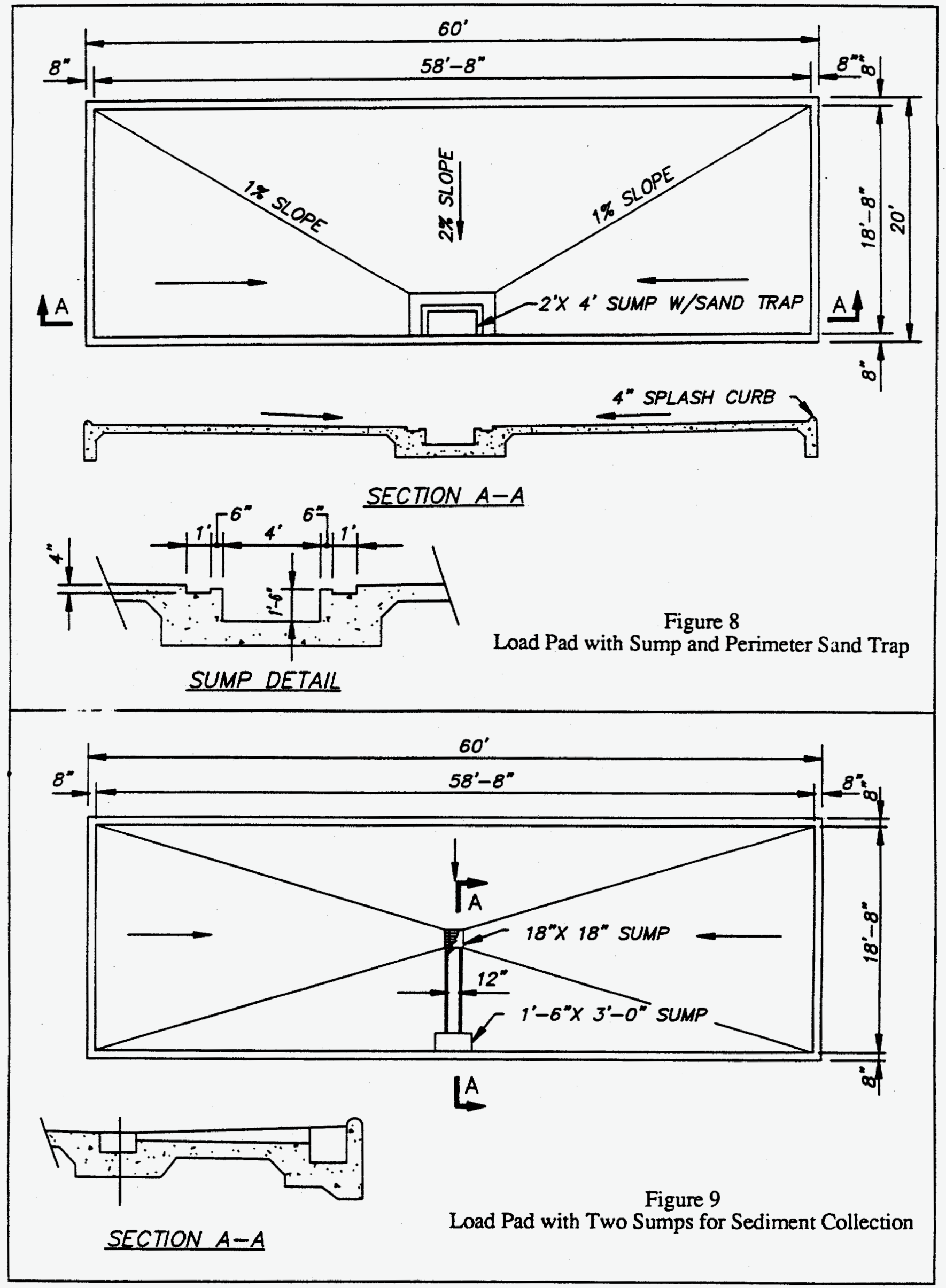


The purpose of a sump is to facilitate the transfer of collected material to a tank. Since leaks cannot easily be detected in sumps, they are not intended for rinsate or spill storage. Consequently, large basins designed for tractor/loader access should never be considered a sump and should never be used to store water containing pesticides or fertilizer. The recommended method for constructing sumps from concrete is to pour them in one pour as part of the loading pad. Contractors prefer to pour the sump floor and sides separately. A waterstop is needed to ensure that the joint between the two pours is watertight. Prefabricated concrete sumps are available which can be fitted with fittings to accept piping from other operational areas.

Liquid railcar loading and unloading areas require some type of spill containment. Liquid holding capacity of the containment will vary among states. One method for containing railcar spills involves paving the area between the tracks and sloping the pavement to a catch basin for checking and/or recovery. Prefabricated pans, with built-in sumps made of fiberglass-reinforced plastic, are available for installation between or on both sides of the rails to collect spills.

\section{Dry Loading Areas}

Pads for loading dry fertilizer must be wide enough to catch all materials spilling over the sides of spreaders or tenders. Since dry granules tend to bounce, pads should extend about ten feet beyond each side of the vehicles being loaded. The edges of the pad should be higher than the center so that granules bounce toward the center and not off the edge of the pad. Shrouds, which attach to the discharge spout of loadout conveyors, can reduce the amount of product which becomes airbome.

Dry material loading pads have no volume requirement. If kept clean, a lockable valve can be used to discharge rainwater or snow melt. As with fluid operations, contaminated rainfall must be handled as a dilute fertilizer/pesticide mixture.

Spills which occur while handling incoming dry materials must also be contained. If storage bins are filled through roof hatches using a portable conveyor, the boot of the conveyor can be placed inside a large tray. Product which spills on the roof of the building or falls underneath the conveyor must also be retrieved. A concrete slab is generally used to collect these spills. An undesirable aspect of portable filling systems is the large area which must be contained. A single, stationary unloading conveyor has the advantage of being easier to contain. Dry fertilizer spills at railcar unloading areas are difficult to reclaim. The area between and on either side of the tracks should be paved to facilitate the cleanup of spilled material. A watertight cover should be fitted over the conveyor opening when not in use. The conveyor opening and surrounding pavement should be designed to prevent runoff from surrounding areas from entering the conveyor. Shrouds are also available which direct product flowing from railcars directly into the conveyor and preventing spills.

\section{Storage Area Containment}

Liquid and dry materials must be stored within a structure which will contain a catastrophic spill, as well as incidental spills or leaks. Earthen dikes lined with clay or synthetic material are satisfactory for fertilizer but not for pesticide (Illinois, 1989). This part of the paper deals with concrete systems. Alternate materials will be described in Part II. 


\section{Liquid Fertilizer Containment}

Secondary containment for liquid fertilizer tanks consists of a basin with a floor and walls that are essentially impervious to liquids. The major considerations are that the walls and floor be strong enough to support the gravity loads of the tanks and the hydrostatic loads of a massive spill with a minimum amount of cracking. It is also important to provide a watertight seal between the floor and wall connection. The basin is usually sloped to a sump where liquid can be pumped to a holding tank or out of the basin.

In containment regulations, the volume of the secondary containment, excluding the space taken up by tanks, varies. Requirements range from at least 100,110 , or 125 percent of the volume of largest tank in the containment. In Illinois, the secondary containment must hold six inches of rain in addition to the volume of the largest tank. Containment regulations were summarized by Peitscher (1991) from information fumished by the Tennessee Valley Authority. Dealers in states which have no containment regulations should use 125 percent of the largest tank for secondary containment volume.

The most difficult aspect of retrofitting secondary containment at a facility is selecting dimensions that will conserve space for vehicle traffic without impeding employee access to the tanks. For example, minimizing dike area provides more space for vehicle movement, but it requires higher dike walls and impedes employee access to tanks. Conversely, minimizing dike wall height facilitates employee access to tanks but can consume space available for vehicle movement.

A typical facility has tanks grouped in one or more clusters. If possible, tanks should be consolidated in one cluster. This usually minimizes wall height since the volume of the containment is based on a single tank. Providing adequate space between tanks will also decrease wall height. In general, 48 inches is the highest practical height for secondary containment walls, even though higher walls can result in a less expensive design due to the reduction in floor area. Higher walls impede employee access, increase problems associated with tanks floating, and expose employees to more risk while inside the wall.

The first step in sizing a secondary containment is to determine the required volume. A scaled drawing of the plan view of the tanks and containment should be made. The net containment area should be determined by subtracting the area of all but the largest tank from the total containment area. The height of the containment wall is determined by dividing the required volume by the net containment area. If the containment wall is higher than desired, the containment area should be enlarged. For example:

Assume containment for four 25,000-gallon tanks is desired. All tanks are 12 feet in diameter and have a flat bottom. The containment floor dimensions are 25 feet by 60 feet. Containment volume must be 125 percent of the largest tank.

Required volume (RV) in cubic $\mathrm{ft}$

$\mathrm{RV}=\mathrm{LTV} \times \mathrm{FF} / 7.5$

Where,

LTV = Largest tank volume in gallons

FF $=$ Freeboard Factor, 1.1 for 110 percent or 1.25 for 125 percent

7.5 = gallons per cubic $\mathrm{ft}$

For this example,

$\mathrm{RV}=25,000 \mathrm{gal} \times 1.25 / 7.5 \mathrm{gal} / \mathrm{cubic} \mathrm{ft}$

$\mathrm{RV}=4,167$ cubic $\mathrm{ft}$

Net containment area (NCA) in square $\mathrm{ft}$

NCA $=$ Total area - tank area

$N C A=(25 \times 60)-\left(3 \times 3.14 \times 6^{2}\right)$

$\mathrm{NCA}=1,500-339 \mathrm{sq} \mathrm{ft}$ 
$\mathrm{NCA}=1,161 \mathrm{sq} \mathrm{ft}$

Note: The area of only three tanks was subtracted since the spilled liquid will occupy space in the leaking tank.

Wall height (WH) in feet

$\mathrm{WH}=\mathrm{RV} / \mathrm{NCT}$

$\mathrm{WH}=4,167 / 1,161=$

$\mathrm{WH}=3.6$ feet, or 43 inches

The required wall height for this design is 3.6 feet or 43 inches.

In secondary containment systems, piping runs should be over and not through the containment wall. If piping must pass through a containment wall, care should be taken to get a good seal between the pipe and wall. The structural integrity of the wall should not be compromised, nor should the liquid holding capacity.

Rain accumulation should be pumped out with a manually controlled pump. Drains should only be used with a lockable valve that is strictly managed to prevent the inadvertent release of fertilizer (South Dakota, 1989). In most states, drains are prohibited (lowa, 1988; Illinois, 1989).

External sight gages used to monitor liquid levels in tanks, are a source of liability because they are easily damaged or broken, thus, releasing the contents of the tank. Sight gages should only be used if a stainless steel valve, which is normally closed, is installed between the bottom of the sight gage and the tank.

Tanks should be anchored to prevent them from floating when empty. The concem is that other tanks in the containment can lose product from damaged plumbing or can rupture from collisions with the floating tank. The simplest way to anchor tanks is to weld three or more brackets to the tank where the sides meet the floor. Each bracket is then bolted to the concrete with anchoring bolts. Chains and tie-down cables can be used with brackets welded above the tank bottom.

Anchoring of tanks is a practice often neglected when tanks are placed in secondary containments. The following example should illustrate the importance of anchoring tanks.

A typical carbon steel tank, 12 feet in diameter and 29 feet high, holds 25,000 gallons of liquid and weighs about 13,000 pounds when empty. An inch of ammonium polyphosphate solution in the tank weighs 825 pounds. Sixteen inches of material in the tank weighs about 13,000 pounds. Exceeding this same level of solution outside the tank will cause the tank to float when empty. If a 36-inch-high containment were full of solution, the buoyancy force pushing upward on the empty tank would be the same as 20 inches of solution in the tank or 16,500 pounds. Shorter tanks of the same diameter weigh less and would float in a shallower depth of liquid. Stainless steel tanks weigh slightly less than carbon steel tanks of the same size, and fiberglass tanks are considerably lighter.

Another design consideration of secondary containment is the method for leveling tanks on the sloped containment floor. The simplest way to level the tanks is to place them in a metal ring filled with coarse, washed gravel. In addition to providing a level surface for the tanks, the gravel provides a space for detecting leaks and also keeps moisture away from the tank bottoms, thus prolonging tank life by reducing corrosion. The objection some dealers have with gravel is the difficulty in cleaning the gravel after a spill. The quality of rainwater could be adversely affected long after a spill has been recovered.

Another way to level tanks is to pour raised concrete pads beneath each tank. This should be done by pouring the tank pads and dike floor in one pour or pouring the tank pads on top of the containment floor. 
Contractors may prefer to pour the tank foundations first and make a second pour for the space between tanks. This is not the preferred method of construction because of the sealing required around tank foundations.

The normal 2-percent slope for concrete can be reduced to 1 percent for secondary containment dike floors because ferilizer contact is less frequent than in operational areas. Many dealers have had success with less slope and tanks setting directly on the floor. The key is to keep the floor dry and free of fertilizer.

Figure 10 shows a typical concrete containment floor and wall construction. Figure 11 shows a containment wall on a floating slab. Floating slabs are common in colder areas where frost depths are such that deep footings are required. A typical secondary containment, showing tank foundations and anchors, is shown in Figure 12.

Dealers not experienced in watertight concrete construction should secure the services of a contractor that is experienced. A brief summary of recommended concrete specifications is given in another section.

Concrete block can be used for secondary containment walls. To withstand the expected loads, block walls must be reinforced with steel and filled with concrete. Some type of sealer should also be used since concrete blocks are not watertight.

\section{Large Tank Containment}

Designing secondary containment for tanks with capacities over 100,000 gallons presents some engineering challenges. These tanks are usually built on sand, providing no barrier to downward movement of leaking material. They cannot be raised with a crane and placed inside a containment. Many dealerships lack adequate space to build a secondary containment dike for these large tanks. State regulations for containing large tanks vary considerably. Proposed methods for containing these tanks are so varied, one state issues experimental permits for designs not explicity defined in the regulations (Illinois Department of Agriculture, 1989).

A detailed discussion of large tank secondary containment has been presented by Waddell and Broder (1991). The key considerations for designing large tank containment will be discussed in this paper.

The basic requirements of large tank secondary containment are as follows:

1. Leakage from the bottom of the tank must be readily detected and prevented from downward movement.

2. The containment volume must be equal to the largest tank in the containment plus some freeboard.

3. Accepted construction materials are concrete, steel, or earth with a synthetic or clay liner. Clay liner permeability can be no greater than that specified in state regulations, typically $10^{-6}$ or $10^{-5}$ centimeters per second.

Dealers have used two basic approaches for providing leak detection for tanks. One involves installing a false bottom inside the tank (Figure 13), and the other involves moving the tank onto an impervious surface. The impact of the two alternatives on the operational efficiency should be considered. For example, if the large tank is not located within a short walking distance of the other operating areas, a considerable gain in efficiency can be realized by moving the tank closer to the rest of the operation. 


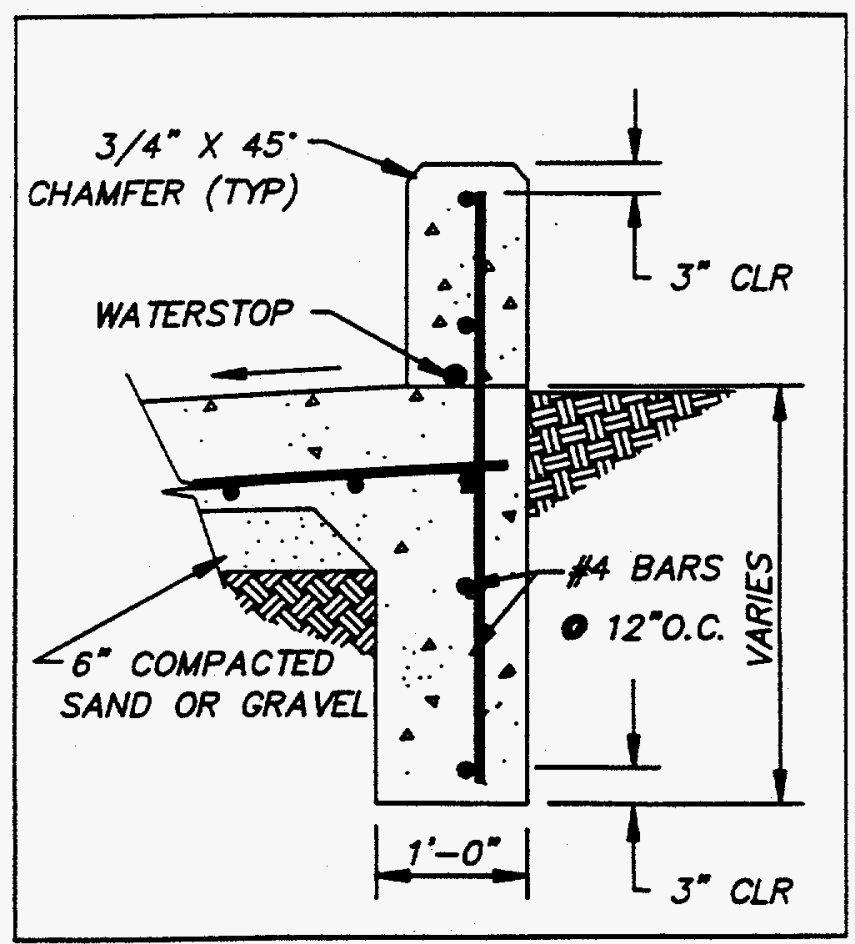

Figure 10

Concrete Containment Wall, Floor, and Footing

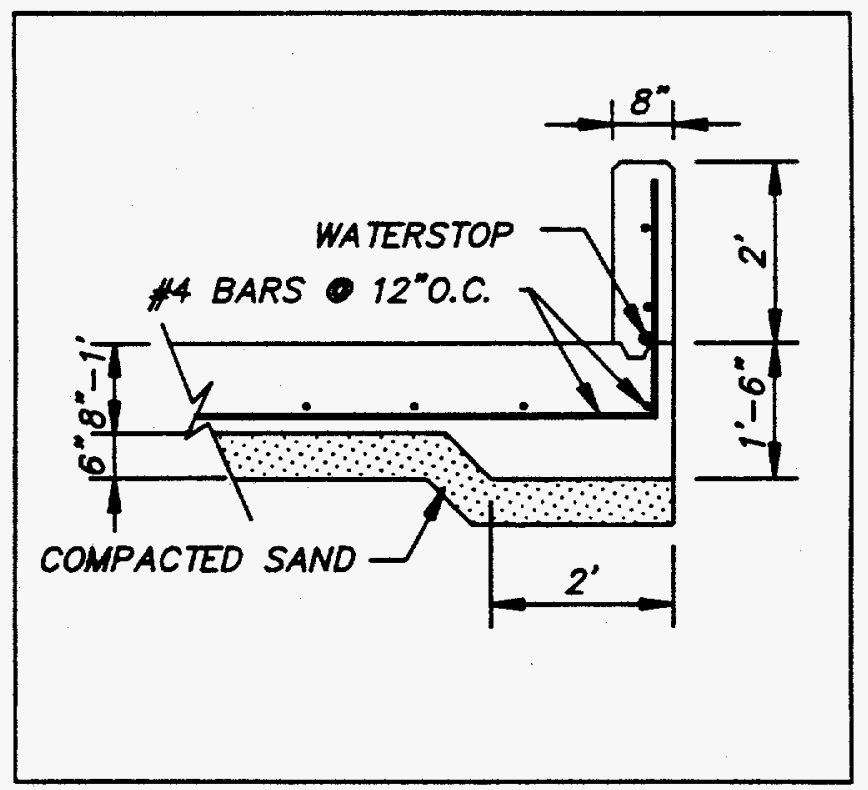

Figure 11

Concrete Wall on Floating Slab 

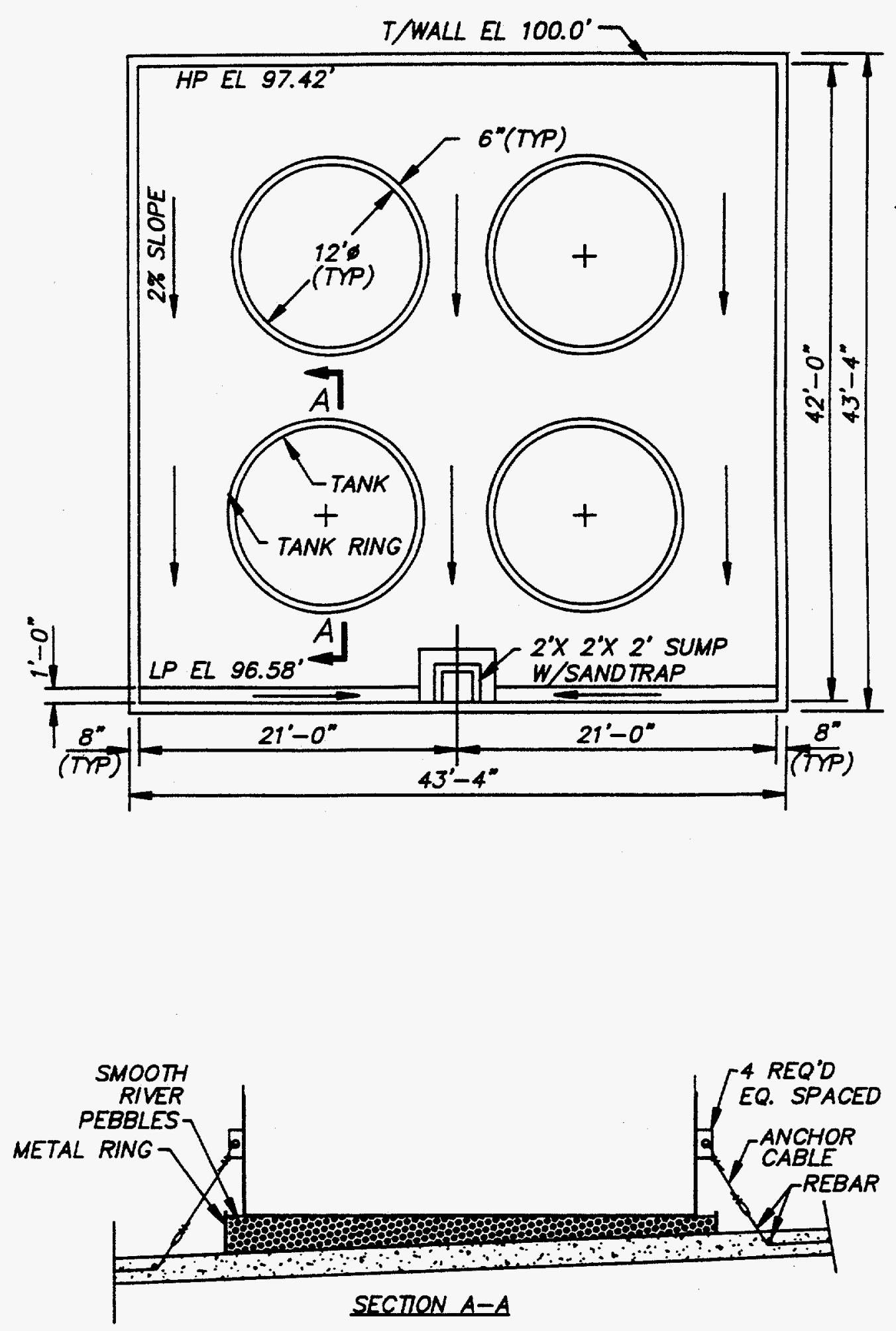

Figure 12

Typical Secondary Containment with Gravel Under Tank and Anchors 


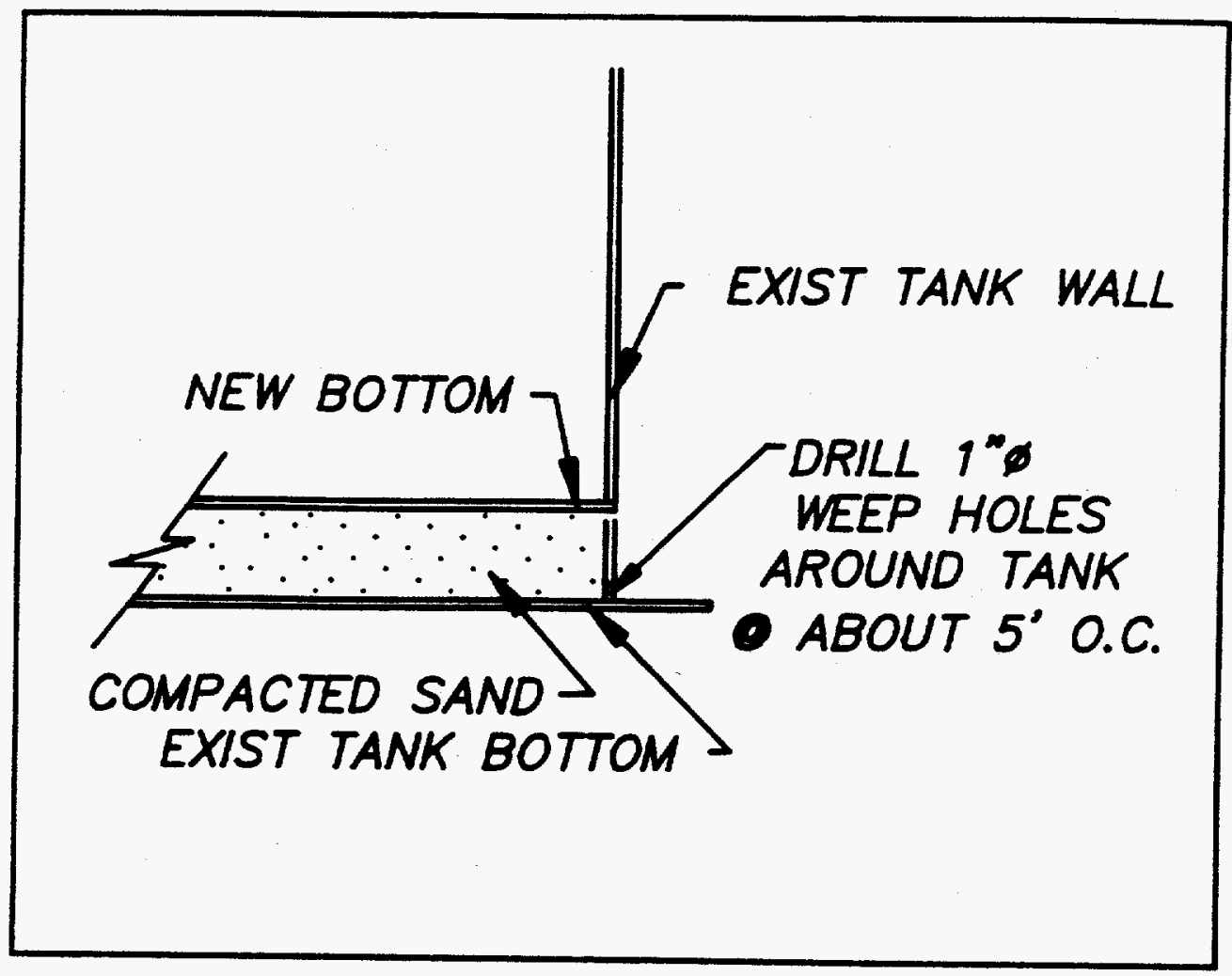

Figure 13

Detail of False Tank Bottom 
A tank relocation may be necessary for other reasons. Close proximity of a tank to a property line may preclude building a dike without moving the tank. The entire facility, including the large tank may need to be relocated, or the present tank location may be undesirable due to poor drainage or some other site characteristic. In some cases, moving the tank to a prepared base can be less expensive than installing a false bottom.

There are several methods for moving large tanks. Since large tanks are easily damaged, an engineer or experienced contractor should be contacted for assistance in moving them. Large tanks have been moved by floating them in water. The upper portion of some large tanks is made of three-sixteenth-inch steel and will float in water no deeper than 12 inches.

Large tanks are commonly moved by the same technique used to move houses. That is,two steel beams are used to transport the tank on semitrailer axles.

An air cushion can also be used to move a large tank a short distance over a relatively smooth surface. The air cushion is made by attaching a skirt around the bottom of the tank and forcing air under the skirt using large blowers welded to the tank. A tractor pulls the tank along on a cushion of air like a hovercraft.

For cost reasons, earthen dikes have been used to contain many large tanks. Earthen dikes are generally less expensive to build than concrete or steel dikes (Waddell and Broder, 1991; Hansen, 1990). Their main disadvantage is that the gravel or soil overburden required to protect the liner from damage will complicate cleanup in the event of a spill. Accumulated precipitation may need to be recycled for months or years before the spilled material is purged from the overburden and no longer contaminates precipitation. For this reason, some dealers prefer concrete or steel containment.

Some large tanks have been contained in a large steel tub to conserve space. The idea is bizarre, but not as impractical as it sounds when one considers that a million-gallon tank requires a dike over an acre in size if the walls are three feet high. The steel containment, coined the elephant ring, for a million-gallon tank occupies an area smaller than one-fifth acre.

Synthetic and clay liners, as well as elephant rings, will be discussed in more detail in Part II of this paper.

Though concrete has rarely been chosen for large tank containment, its use has been proposed at a site where two tanks will be floated to a prepared base. Concrete was chosen for its easy cleanup, paricularly when the dike is drained after moving the tanks. The cost of the two false bottoms was a key factor in the decision to move the tanks. Structural integrity of the system should not be compromised for the sake of economy. Guidelines for watertight concrete should be followed for all concrete in containment design.

Large tanks should also be anchored or elevated above the dike floor to prevent them from floating when empty. Weights can be attached to the tanks or the tanks can be anchored using cables anchored outside the tanks (Kammel, et al., 1991). It also is a good practice to leave fitings and manholes open when tanks are empty to equalize liquid levels inside and outside the tank in the event of a spill or rainfall accumulation.

\section{Pesticide Storage Containment}

Pesticide storage containment is similar to fertilizer storage containment with the exception that earthen containments are not permitted for pesticides. It is also important to separate pesticide containment from fertilizer containment. The two can be adjacent inside one containment with a dividing wall between 
the two. The dividing wall can be lower than the outside wall to allow material in the two areas to mix during a catastrophe. Pesticides should also be kept under roof because of the problems associated with contaminated rainwater.

Packaged pesticides should be stored in a separate warehouse and not inside a secondary containment for bulk pesticides or fertilizer. Flammable pesticides should be separated from nonflammable ones, and the warehouse should be curbed to contain any water used in extinguishing fires.

\section{Dry Fertilizer Storage}

Dry fertilizer containment involves storing material in a building that has a roof, walls, and floor that prevent fertilizer from coming in contact with precipitation or surface water. Dry fertilizer storage buildings should be on elevated ground to prevent rainfall runoff from entering the building. The floor should be paved with concrete, and cracks should be repaired to prevent the downward movement of fertilizers. The roof and walls should be free of leaks that will allow rainwater to come in contact with fertilizer. Floor sweepings and scrap fertilizer materials should be kept under roof the same as other dry fertilizers. Limestone is generally the only dry fertilizer material that can be stored outside.

Until recently, wood was the material of choice for dry fertilizer buildings. Some new buildings are being made primarily of reinforced concrete. The floor is poured with slots wide enough for walls to be stood edgewise in them. Wall sections are then poured horizontally on the floor. Reinforcement steel and clips for connecting wall sections are accurately placed in each wall section. A crane is then used to erect the walls and connect adjoining panels. The bin walls are supported laterally across the top of the open end with steel or concrete beams. The advantage to this type of construction is the savings in labor compared to wooden buildings.

\section{Watertight Concrete Construction}

To ensure that concrete for load pads and containment structures will resist penetration by moisture and chemicals, specifications for watertight, corrosion-resistant concrete should be followed (MWPS 37, 1991; TVA Bulletin Y-223, 1991; PCA, 1989). Watertight concrete has a low water-to-cement ratio (0.4 to 0.45), has large, well graded aggregate, and is air entrained. To ensure that concrete attains its design strength and waterightness, it should be moist cured at least 14 days, preferably 28 days.

In addition to the proper mix and curing, other design practices should be followed to maximize the life and performance of concrete containment structures. Expansion joints should be spaced close enough to prevent cracks from forming in undesirable places. The rule of thumb is that the minimum joint spacing in feet be two and one-half times the slab thickness in inches. That is, an 8-inch slab should have joints no farther than 20 feet apar. Joints should be machine cut to a depth of one-fourth to one-third the slab thickness. The cuts should be made as soon as concrete has set and before shrink cracks occur (four to twelve hours, depending on drying conditions). Joints should be located in areas where they can be monitored, for example, not under a tank. The sections between joints should be square. If not square, the length-to-width ratio should not exceed 1.5 .

Joints should be sealed with a material resistant to ferilizers and pesticides and should be periodically checked for repair or replacement. A bond breaker, made from a polyethylene strip or a pressure-sensitive tape, should be provided in the bottom of the slot to allow the sealant to change shape without a concentration of stress on the bottom (Figure 14). A bond breaker will increase the life of the seal if the 
joint becomes active (increases in width). A vapor barrier should not be used beneath pours because this may cause the concrete to retain moisture and increase concrete degradation from freezing and thawing.

Frost heave problems and moisture problems can be reduced by keeping the area around concrete slabs dry. The area beneath the concrete should be higher than the surrounding area, and surface drainage should be provided to keep water from standing near containment structures. The drainage around concrete structures should be monitored for two or three years after construction to ensure that the area is well drained after the structure settles. Runoff from buildings and paved areas should be kept away from containment sites using curbs and gutters.

Steel reinforcement bars are recommended for containment structures. Wire mesh or fiber additives will not provide resistance to cracking over the life of the facility. In most instances, reinforcement rod is spaced every 12 inches and in both horizontal directions. The steel in sumps is usually spaced 6 inches apart. Since the amount of reinforcement steel is dependent on several design factors, such as tank size and the bearing strength of the subbase, an experienced contractor or engineer should be consulted regarding reinforcement requirements. To prevent secondary containment basins from leaking beneath the containment wall, waterstops are needed between containment floors and walls. Molded vinyl waterstops are available in several shapes. These must be embedded in the concrete floor beneath the wall. Other waterstops are available which can be placed on the perimeter of the slab after it has cured.

Many fertilizer and pesticide handling facilities have concrete slabs beneath tanks that may be incorporated into a secondary containment design by attaching walls. The suitability of the slab for supporting the walls should be determined. In most instances, the support provided by the slab is not suitable for walls; however, if the concrete is in good condition and free from cracks, it can serve as part of the containment floor and the pad can be extended. The walls then can be built above new concrete having a proper footing (Figures 10 and 11).

It is important when joining new concrete to old concrete to seal the crack between the two slabs and to connect the slabs using dowels inserted into holes drilled into the existing concrete. The technique used to seal control joints should be used to seal the crack between new and existing concrete. That is, a rectangular groove with a bond breaker in the bottom should be made at the interface of the two pours. If an existing concrete slab is in good condition, but is not properly sloped or is in a poorly drained area, the best decision may be to remove the concrete or pour a new slab over it. A slab which is badly corroded should not be used as a base for new pours because the material causing the corrosion can attack the new concrete from beneath. An engineer experienced in concrete design should be consulted regarding the use of existing concrete.

Dormant cracks in concrete should be sealed, as are control joints. Working cracks are a result of a structural deficiency which must be corrected before the crack can be sealed. If the crack is subject to hydrostatic pressure from beneath, this should be corrected first; otherwise, the seal will fail. The key to good performance of sealants in cracks is to enlarge the crack along its exposed surfaces so that it resembles a machine-cut control joint. The crack should be machine routed, dried, and the dust removed using an air jet or sand blaster before placing the sealant.

Due to the corrosive effect that some fertilizers and pesticides have on concrete, dealers may want to consider coating concrete surfaces which come in frequent contact with corrosive materials. Preliminary results from concrete corrosion tests being conducted at NFERC indicate that urea-ammonium nitrate solution (UAN) is extremely corrosive to all concrete specimens tested. If a serious effort is not made to prevent UAN from contacting concrete, dealers may want to consider adding a protective coating to the 

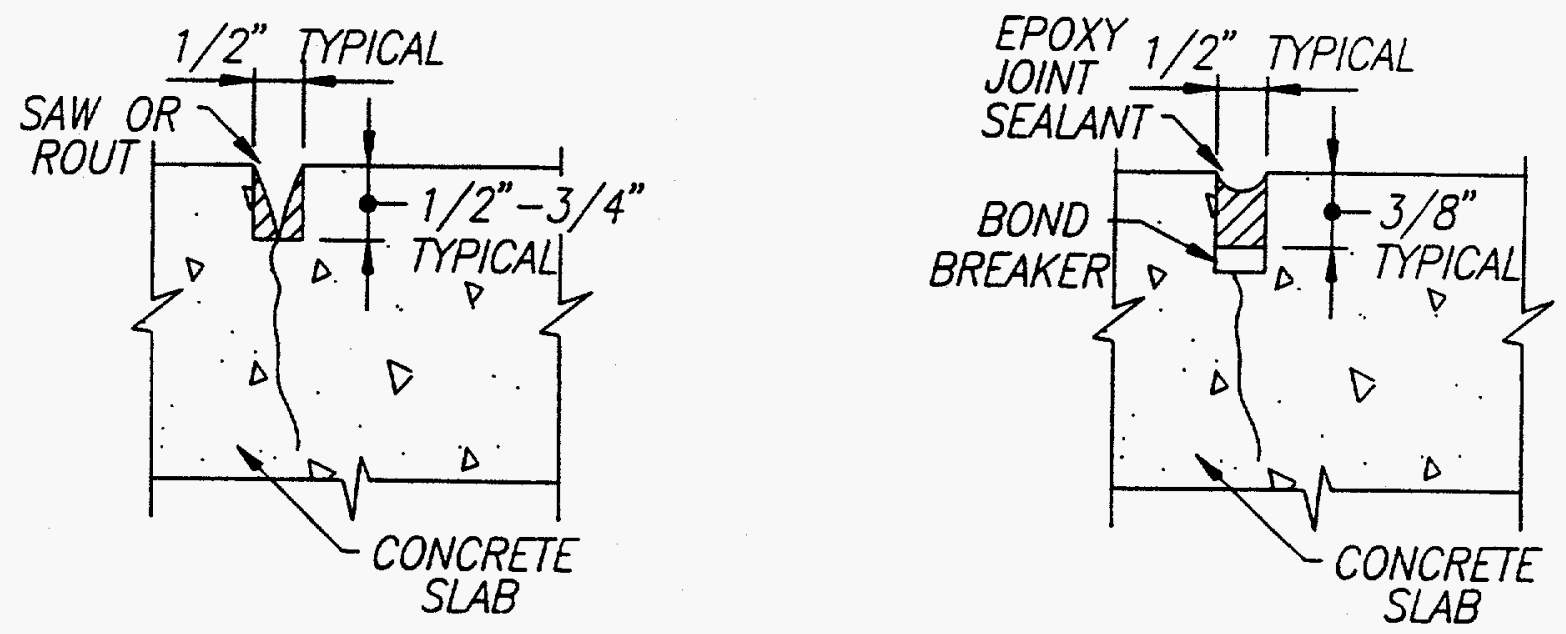

Figure 14

Concrete Crack Repair and Joint Sealing 
concrete surfaces that come in contact with UAN. Phosphoric and sulfuric acid are also extremely corrosive to concrete.

There are a number of coating materials which can protect concrete from the corrosive effect of fertilizers. The main factors which affect the coating selection are service conditions and the fertilizer. Service conditions refer to the type of fertilizer contact, for example, constant emersion or intermittent spills. The types of traffic (foot traffic, vehicle traffic) and types of tires are also service conditions. ACI has published an excellent guide on coatings for protecting concrete from most chemicals (ACI, 1989).

In general, thin-film penetrating sealants are not recommended for corrosive matcrials such as acids or UAN solution. A high-build, epoxy-based coating or other type of resin coating is normally recommended. The adherence properties and moisture sensitivity of these resin coatings can vary. Generally, these coatings require an experienced or certified applicator. The installed cost of these types of coatings range from \$2.50 to $\$ 12.00$ per square foot and are, consequently, too expensive for most fertilizer dealers to use in large areas. Dealers may want to consider protecting areas subject to frequent exposure from corrosive materials, such as the bases of acid pumps, UAN spill areas, or sumps. A corrosion specialist or coating expert should be consulted for assistance in selecting a coating for concrete.

The approach taken by most dealers is to minimize concrete exposure to corrosive fertilizers. This is done by using pans or buckets to collect drips from uncoupling hoses, by maintaining pump seals, by accurately metering product into vehicles and tanks to prevent overfilling, and by immediately cleaning up fertilizer spills. By using these management practices, dealers can considerably increase the life of their concrete.

\section{Retrofitting: Case Studies}

The following case study illustrates how a fairly large liquid fertilizer facility was upgraded to comply with state containment regulations. Improvements were made in the operational efficiency of the facility; however, there was a slight increase in labor associated with the management of stormwater and sediment collecting on the loading pad.

The original facility (layout is shown in Figure 15) was typical in that fertilizer tanks were spread around the property and liquid products were loaded and unloaded at more than one location, only one of which was paved. The paved loading area, however, was not sloped to convey spills and rinsate to a sump and was not large enough to collect the spray from equipment washing. A railroad spur for receiving liquid and dry fertilizer raw materials passed through the center of the propeny, separating many of the liquid fertilizer storage tanks from the liquid product mixer. Products from these tanks were conveyed to the mixer through pipes buried beneath the railroad spur.

The principal products sold from the facility are custom blended liquid and suspension fertilizers. Bulk and packaged pesticides are added to fertilizers in the mixer. Some anhydrous ammonia and dry blended fertilizer are also sold. Ammonium polyphosphate solution is manufactured onsite by a porable reactor supplied by another company.

The most difficult decision which had to be made regarding the final design was the location of the fertilizer tanks. Considerable thought was given to keeping tanks on both sides of the railroad spur. The final layout (Figure 16) shows that all the horizontal fertilizer tanks were retired, and the upright tanks were consolidated in one area on the north side (same side as the liquid mixer) of the railroad spur. A drainage ditch at the site of the new tank farm had to be moved to the northern edge of the property along a railroad. 


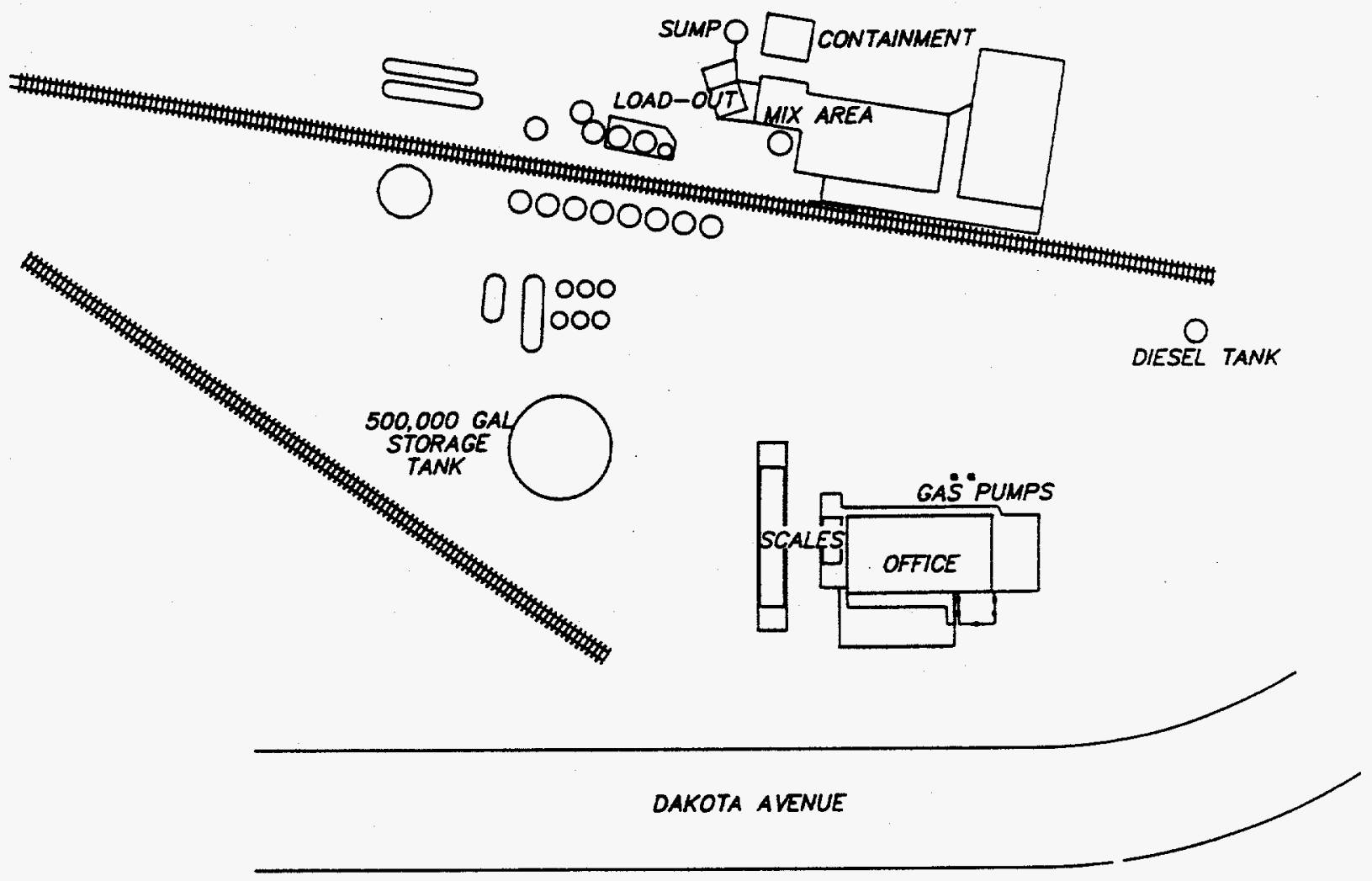

Figure 15

Liquid Fertilizer Dealership Original Site Plan 


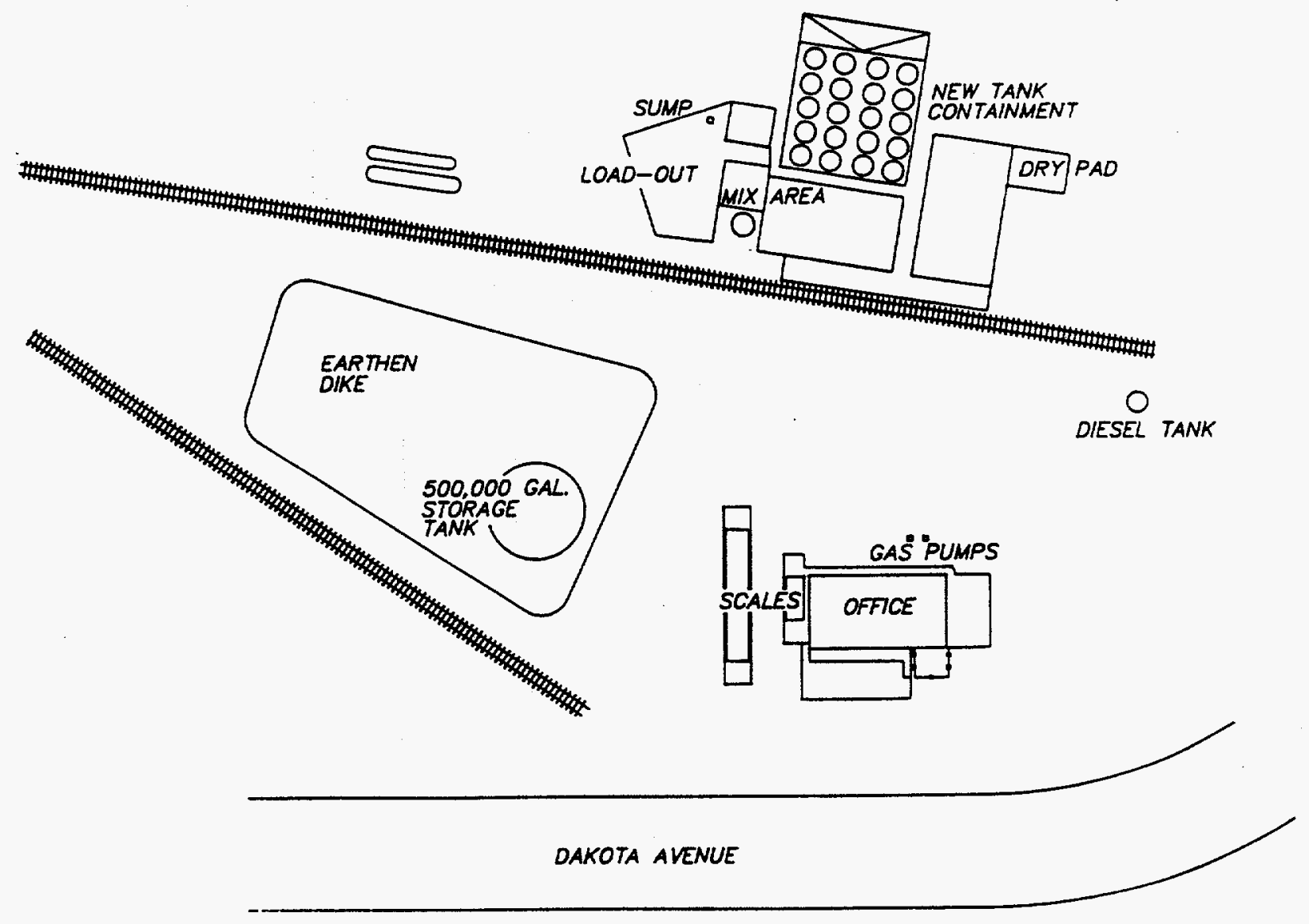

Figure 16

Liquid Fertilizer Dealership

Site Plan after Being Contained 
The existing bulk pesticide secondary containment dike had block walls which had to be sealed with an epoxy coating. A second bulk pesticide dike was built adjacent to the existing dike. Future plans call for building a roof over the bulk pesticide storage area.

The existing loadout pad was removed because its flat design made it unsuitable for incorporating into a larger pad. The new pad was made large enough for equipment washing and has a liquid holding capacity of about 11,000 gallons. State regulations require that the pad volume be equal to the volume of the largest tank loaded on the pad. Due to an error in forming the perimeter of the slab, the potential liquid holding capacity was not originally realized. While inundating the slab to determine its actual volume, it was leamed that a short section of the perimeter was about three inches lower in elevation than the rest of the perimeter. This experience prompted the recommendation that loading pads be flooded after construction to verify their liquid holding capacity. This can also be done to wet cure the slab.

Though not required by law, a raw material unloading pad was built adjacent to the tank farm. This pad will also be used to load out raw materials for direct application.

Mixer secondary containment was achieved by installing a concrete curb on the existing mixer room floor.

The only dry fertilizer containment required was at the loadout conveyor since the blender was located inside the dry fertilizer storage building. A concrete pad, 16 by 20 feet, was poured to collect material spilled while loading dry fertilizer. A unique requirement in the state where this facility is located is leak detection beneath the liquid fertilizer secondary containment dike. This was accomplished using perforated tile spaced on 10-foot centers in the gravel beneath the concrete slab. A 30-mil oil-resistant PVC liner was placed beneath the gravel.

Secondary containment has not been built for the large tank (capacity 500,000 gallons). Figure 16 shows an earthen dike with a synthetic liner around the tank at its original location. Space north of the railroad spur is not adequate for constructing a dike. A synthetic liner was chosen because it is less expensive than concrete or steel, and clay-lined dikes are prohibited by the state. Either a false bottom will be placed inside the tank for leak detection or the tank will be raised and a synthetic liner placed beneath it. The pipe to the mixer will remain above ground except at the railroad spur where it will be buricd and placed inside a larger pipe.

One interesting management practice used at this facility involves the handling of sediment in the loadout pad sump. Since the sediment contains pesticides and has too many solids to be recycled into liquid blends, it is dried in pans and mixed in small proportions with dry fertilizer. The raw material loading pad was elevated so that its spills and rinsate could be drained to the main loading pad and handled in the main sump. 


\section{Summary of Concrete Systems}

Concrete is the material of choice for most containment structures because it is relatively inexpensive and provides an adequate barrier to the downward movement of pollutants, while providing structural support for vehicles and product loads. Though concrete is subject to corrosion from some fertilizer products, a service life of 20 years can be expected for concrete structures properly designed, installed, and maintained.

The problem of degradation of concrete from some ferilizers needs further research. Though some concrete admixtures have been shown to be effective in reducing corrosion, they are relatively expensive. The effect of pesticides on concrete and their potential to penetrate the concrete also need to be researched. Concrete coatings should be tested to determine which coatings provide adequate protection from corrosive fertilizers. The benefits of immediate spill cleanup and other management practices for extending the life of concrete should be determined.

\section{Part II: Alternative Materials}

\section{Introduction}

Though concrete is the most important construction material for containment structures, several alternative materials are used. Carbon steel plates are welded together to form a large tub, "elephant ring," for secondary containment for large tanks. Earthen dikes with clay or synthetic liners are used for large tank diking. Stainless steel plate has been used to fabricate sumps for insertion in concrete loading pads. Portable loading pads are fabricated from synthetic liner material as well as from carbon steel. Fiberglass reinforced plastic has been used in fabricating loading pads for collecting spills from railcar unloading sites. Following is a more detailed discussion of how altemative materials are used in secondary containment structures.

\section{Steel}

The one advantage which steel has over other materials is that it can be used to conserve space. Steel's strength permits the construction of higher dike walls than practical with other material. As described in Part I of this paper, an elephant ring requires about five times less space than an earthen dike with a 3-foothigh berm.

An elephant ring is typically about half as deep as the tank is high and has a diameter 1.5 times that of the tank. The tank and tub combined require nearly twice as much steel plate to build as does the tank.

An important consideration regarding elephant rings is the confined space that exists between the tank and the ring. Local health and safety standards may require special entry procedures to ensure that employees entering the space between the tank and ring can be retrieved in the event of an accident. Because of this concern for employee safety, some states restrict dike wall height to no more than 4 or 6 feet.

The two disadvantages of steel are its high cost and maintenance. Since carbon steel is subject to corrosion, a coat of paint must be maintained on its surface.

Stainless steel is an ideal material for service in corrosive fertilizer environments; however, its high cost has restricted its use to prefabricated sumps. Figure 17 shows a typical stainless steel sump which has 


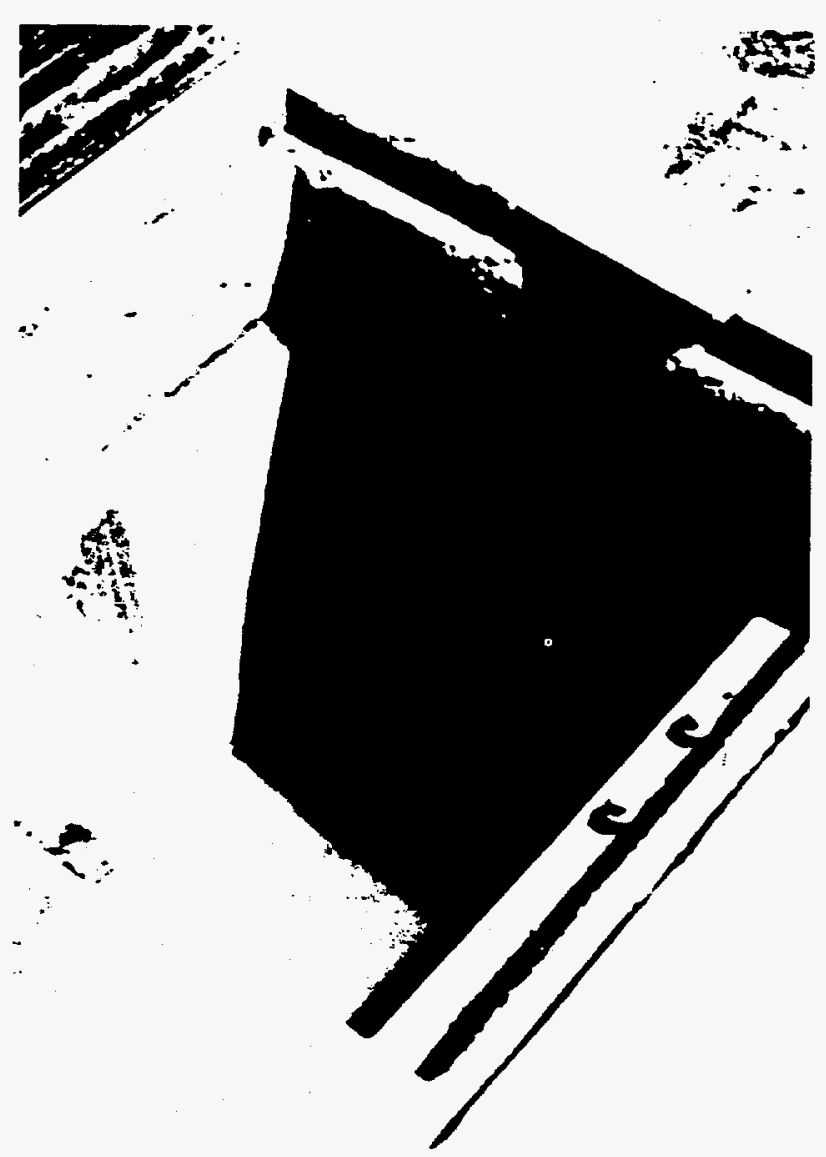

Figure 17

Stainless Steel Double-Walled Sump

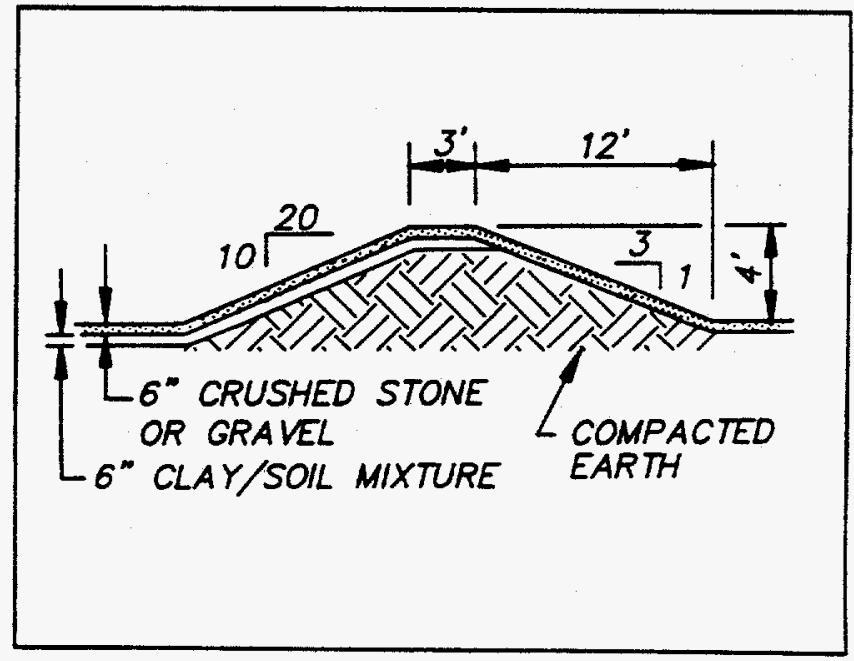

Figure 18

Clay-Lined Earthen Dike 
a double wall and an access port between the two walls to check for leaks in the inner wall. Portable truck loading pads have been fabricated from steel plate and square tubing. Four-inch square tubing is used on the perimeter of the structure with steel plate in the bottom. Retractable wheels are attached to one end of the structure and a hitch point is mounted on the other end. Portable loading pads may become more popular as farmers are required to provide spill collection at pesticide applicator loading sites.

\section{Synthetic Liners}

Synthetic liners are commonly used for large dikes because they are simple to install, are less expensive than concrete or steel, and provide a high level of impermeability. Disadvantages are that they are easily punctured and are difficult to clean up after a spill. Spill cleanup is complicated by the gravel or soil cover which is generally used to protect the liner from physical damage.

Since synthetic liner materials are stabilized to resist degradation by ultraviolet radiation, the gravel or soil cover is only needed to protect the liner from physical damage. To avoid the problems associated with cleaning a spill in the overburden, manufacturers are offering liner materials which do not need a gravel cover. Gravel or sand is still needed beneath the tank to protect the liner from the weight of the tank and to provide leak detection. Five synthetic liner materials are now being marketed for agrichemical secondary containment: high-density polyethylene (HDPE), chlorosulfonated polyethylene (hypalon), polyvinylchloride ( $\mathrm{PVC}$ ), polysulfide, and acrylonitrile polybutadiene. Polysulfide liners are made in the field by spraying the polysulfide resin over a sheet of geotextile (a fabric liner designed for placement on the ground). The other liners are sold in sheets and are cut and seamed at the factory or onsite.

Tensile strength and puncture resistance are key physical properties to consider when choosing a liner. Chemical resistance must also be considered since acids, petroleum, and organic solvents contained in pesticides can degrade some liner materials. Reliability and durability of synthetic liner systems originate with the engineers who select the liner and prepare the specifications. To insure proper installation, the liner should be installed by experienced personnel. A more thorough discussion of synthetic liners is given by Waddell and Broder (1991).

Regulators and dealers in many states have given considerable attention to the use of bladders for secondary containment of large tanks. Bladders made from PVC are being installed inside large tanks to serve as primary containment while the tank serves as secondary containment. Bladders have been used for years to protect carbon steel tanks from corrosive chemicals and to make wooden tanks wateright. The current interest in bladders stems from the fact that they eliminate problems associated with stormwater collection and management and they are less expensive than other large tank secondary containment systems.

A typical bladder system has three main components a sand layer beneath the bladder for leak detection, the bladder, and a geotextile between the bladder and the tank wall. The geotextile is needed to protect the bladder from projections in the tank wall and to allow liquid between the bladder and tank to flow to the sand layer for leak detection.

Dealers considering a bladder for secondary containment should seek approval from state regulators. Some states may require approval by a registered professional engincer or may require that the system's performance be verified before granting a permit. 


\section{Clay Liners}

Clay has been used for years to seal ponds and other primary storage basins. However, there are substantial differences between this application and the use of clay for secondary containment. Secondary containment basins are normally empty, and drying and cracking of the clay liner becomes a significant concem. Also, the lack of a sufficient layer of water above the reservoir increases the risk of frost damage in northern climates. These problems can be overcome by using an adequate soil cover over the clay: Clay liners, however, are not completely impermeable and are, therefore, not permitted for pesticide secondary containment. For fertilizer secondary containment, a permeability $1 \times 10^{-6} \mathrm{~cm} / \mathrm{sec}$ is considered acceptable in most state regulations (Illinois, 1989; lowa, 1988; and Wisconsin, 1988). Minnesota has a maximum seepage rate of 0.125 inches per day (Minnesota, 1989).

Most clay liners, which have been installed beneath large fertilizer tanks, have been made by compacting clay soil located at the site or obtained locally. A series of laboratory tests of the engineering properties of the soil are required to determine if the soil can be compacted to obtain the desired permeability. Laboratory tests also provide information necessary for construction specifications and quality control. These studies may also dictate that the soil be screened to remove rock or organic matter.

A detailed discussion of the soil properties which influence natural clay liners has been given by Morrison (1991).

In most locations, clay sources are not available in large enough quantities to build a large containment dike. In these cases, the desired permeability can be achieved by adding sodium bentonite to existing soil. Sodium bentonite is a clay with excellent swelling properties which is commonly used to decrease the permeability of soil. Generally, the addition of 3 to 8 pounds of sodium bentonite per square foot will decrease a soil's permeability to the desired level. Figure 18 shows a typical bentonite/soil dike design with a 6-inch gravel cover.

The proper application rates of bentonite are determined by a series of compacted permeability tests on mixtures of bentonite clay and representative samples of the soil to be amended. The clay supplier gencrally conducts these tests and makes a recommendation regarding the amount of clay and particular formulation required to achieve a desired permeability. A more thorough discussion of bentonite amended soil liners has been presented by Trauger (1992). One of the most interesting developments in clay liner technology is geosynthetic clay liners (GCL). These liners have a layer of pure sodium bentonite sandwiched between two layers of geosynthetic material. These products have an advantage over conventional clay liners in that they are much easier to install and have more uniform hydraulic properties. They have an advantage over synthetic liners in that a physical bond is not required at the seams-adjacent sheets are merely overlapped. The swelling ability of hydrating bentonite makes GCLs less susceptible to damage during installation than synthetic liners because small punctures seal themselves upon hydration. The permeability of GCLs is generally around $1 \times 10^{-9} \mathrm{~cm} / \mathrm{sec}$, much lower than that required for fertilizer containment.

Like conventional clay liners, GCLs must be covered to reduce the potential for desiccation and freeze/thaw cycling. Research has shown, however, that GCLs perform better than compacted clay liners or bentonite-amended liners when exposed to freeze/thaw and desiccation/rehydration cycling. The combination of pure bentonite and geosynthetic liners to facilitate uniform placement makes GCLs the highest performance clay-based secondary containment liners. A more thorough discussion of GCLs has been given by Trauger (1992). 


\section{Rigid Plastics and Other Prefabricated Items}

Railcar unloading areas can be contained using a prefabricated loading pad made from fibcrglassreinforced plastic. The loading pad has a built-in sump and has three panels-one which snaps into position between the tracks and two side pans which are held in place by backfill.

Portable truck loading pads made of hypalon are available in several sizes. These pads resemble a rubber raft in that the perimeter of the pad is an inflated tube. The pad can be installed on a smooth, rock-free surface; or a geotextile can be used beneath the pad to protect it from sharp objects which could puncture it.

Rotationally molded polyethylene tubs are available in a number of sizes for use as secondary containment dikes. Another innovation in rotational molded polyethylene is a double-walled tank with a watertight cover to keep rain out. The outer wall serves as secondary containment for the tank which is made by the inner wall.

The supplier of sulfur concrete is marketing a prefabricated rectangular sump which has a capacity of 125 gallons. Sulfur concrete has a specially formulated granular sulfur as a binder instead of Portand cement. It is made by heating a mixture of sulfur and aggregate to a temperature of about $300^{\circ} \mathrm{F}$ before pouring it into molds or forms. Unlike Portland-cement-based concretes, sulfur concrete will not corrode when exposed to strong acids or fertilizer salts. In tests conducted at the NFERC, sulfur concrete specimens were not affected by urea-ammonium nitrate solution, while Portland-cement-based specimens were destroyed. Despite its corrosion-resistant properties, sulfur concrete has not been used for retail fertilizer containment because it is several times more expensive than Portland-cement-based concrete.

\section{Summary of Alternate Materials}

There are a number of secondary containment applications well suited for materials other than concrete. In large tank secondary containment, a combination of materials is common. False bottoms, made of steel, can be used for leak detection, while the dike can be lined with clay or synthetic material. Dealers who are considering alternative materials should first seek regulatory approval. Some states may require written guarantees conceming the compatibility of the liner material with fertilizer or concerning the expected life of the liner. Aside from large tanks, alternative materials are well suited to portable containment systems. As agrichemical equipment suppliers become aware of the market potential for prefabricated containment structures, a wider variety of prefabricated structures should become available. As secondary containment regulations begin to include farmers' facilities, the demand for portable containment systems should increase, thus increasing the demand for prefabricated structures.

\section{Conclusions}

Before designing a complete containment system, dealers should visit sites and study existing systems. Dealers with containment systems are a valuable source of information, particularly if they have operated a system for some time. Experience and hind-sight are invaluable.

A good system design should incorporate methods for expanding in the future. Provisions for the construction of roofs over areas subject to incidental spills should be included in the long-range plan.

Even in states where there are no containment regulations, dealers should contact local agencies involved with water supplies, such as the Health Department, Local Emergency Management Agency, and 
the local Environmental Regulatory Agency, when modifying a facility. For assistance in designing containment, the Cooperative Extension Service, State Department of Agriculture, fertilizer and agrichemical dealer organizations, and TVA's National Fertilizer and Environmental Research Center can bc contacted.

Fertilizer and pesticide containment provides opponunities for the retail fertilizer industry to take a leadership role in protecting our soil and water resources. Indications are that there will be more and not less regulation for fertilizer and agrichemical dealers in the future. 


\section{References}

Broder, Michael F., and Carl A. Cole, 1989. "Minimizing Hazardous Waste From Application of FertilizerPesticide Mixtures," presented at summer meeting, American Institute of Chemical Engineers. (Unpublished, National Fertilizer and Environmental Research Center, TVA, Muscle Shoals, AL).

Portland Cement Association, 1989. "Effects of Substances on Concrete and Guide to Protective Treatments," Concrete Information.

Hansen, T. L. 1990. "Diking Alternatives for Secondary Containment of Liquid Fertilizers," Dultmeier Engineering Services, Inc., Omaha, NE.

Hargett, Norman, L., and Janice T. Berry. 1988. "Today's Retail Ferrilizer Industry," National Fertilizer and Environmental Research Center, TVA, Muscle Shoals, AL.

Illinois Department of Agriculture, 1989. Part 255 Agrichemical Facilities; Subchapter i; Pesticide Control; Title 8: Agriculture and Animals, Springfield, IIL.

Iowa Department of Agriculture. 1988. Bulk Commercial Fertilizer Storage, Article 12:44, Chapter 12:44:05, Des Moines, IA.

Kammell, D. W., G. L. Riskowski, R. T. Noyes, and V. L. Hofman. 1990. Designing Facilities for Pesticide and Fertilizer Containment, Midwest Plan Service, Agricultural Engineering, lowa State University, Ames, IA.

Minnesota Department of Agriculture. 1989. Bulk Pesticide Storage Facility Rule Summary, Agronomy Services Division, St. Paul, MN.

Morrison, P. 1991. "Use of Clay As A Lining Material for Fertilizer Secondary Containment." Proceedings of Materials of Construction Symposium, September 1991. TVA/NFERC Muscle Shoals, AL.

Noyes, Ronald T., 1989. "Modular Concrete Wash/Containment Pad for Agricultural Chemicals," Paper No. 891613, American Society of Agricultural Engineers, St. Joseph, MI,

South Dakota Department of Agriculture. 1989. Bulk Commercial Fertilizer Operations Manual, Division of Regulatory Services, Pierre, SD,

Tomlinson, Susanna, and Carl A. Cole, 1989. "Do an Environmental Analysis of Your Plant," published in Farm Chemicals, Summer Issue,

Trauger, R. 1992. Clay Systems For Above Ground Tank Secondary Containment Systems. Colloid Environmental Technologies Company, Arlington Heights, IL.

Waddell, Edward L. and Broder, Michael F. 1991. "Secondary Containment for Large Tanks," presented at National Symposium on Pesticide and Fertilizer Containment Design and Management, February, 1992. (Unpublished National Fertilizer and Environmental Research Center, TVA, Muscle Shoals, AL).

Wisconsin Department of Agriculture, Trade \& Consumer Protection. 1988. "Chapter Ag 162, Bulk Fertilizer Storage," Wisconsin Administrative Code, Register, February 1988, No. 386, Madison, WI. 